\title{
Evolution of Endolymph Secretion and Endolymphatic Potential Generation in the Vertebrate Inner Ear
}

\author{
Christine Köppla, b Viviane Wilms ${ }^{c}$ lan John Russell ${ }^{d}$ Hans Gerd Nothwang ${ }^{b, c}$ \\ ${ }^{a}$ Cochlea and Auditory Brainstem Physiology, Cluster of Excellence "Hearing4All", School of Medicine and Health

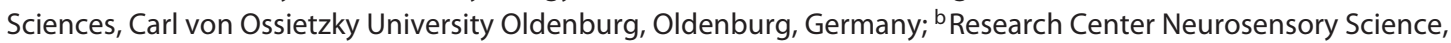

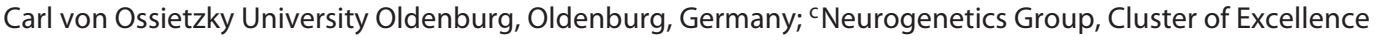 \\ "Hearing4All", School of Medicine and Health Sciences, Carl von Ossietzky University Oldenburg, Oldenburg,

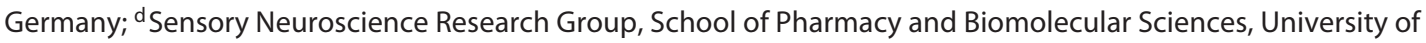 \\ Brighton, Brighton, UK
}

\section{Keywords}

Cell type · Cupula · Evolutionary development ·

High-frequency hearing · Lateral line · Microenvironment ·

Transcription factor · Vestibular system

\begin{abstract}
The ear of extant vertebrates reflects multiple independent evolutionary trajectories. Examples include the middle ear or the unique specializations of the mammalian cochlea. Another striking difference between vertebrate inner ears concerns the differences in the magnitude of the endolymphatic potential. This differs both between the vestibular and auditory part of the inner ear as well as between the auditory periphery in different vertebrates. Here we provide a comparison of the cellular and molecular mechanisms in different endorgans across vertebrates. We begin with the lateral line and vestibular systems, as they likely represent plesiomorphic conditions, then review the situation in different vertebrate auditory endorgans. All three systems harbor hair cells bathed in a high $\left(\mathrm{K}^{+}\right)$environment. Superficial lateral line neuromasts are bathed in an electrogenically main-
\end{abstract}

\section{KARGER}

(C) 2018 S. Karger AG, Basel

E-Mail karger@karger.com

www.karger.com/bbe tained high $\left(\mathrm{K}^{+}\right)$microenvironment provided by the complex gelatinous cupula. This is associated with a positive endocupular potential. Whether this is a special or a universal feature of lateral line and possibly vestibular cupulae remains to be discovered. The vestibular system represents a closed system with an endolymph that is characterized by an enhanced $\left(\mathrm{K}^{+}\right)$relative to the perilymph. Yet only in land vertebrates does $\left(\mathrm{K}^{+}\right)$exceed $\left(\mathrm{Na}^{+}\right)$. The endolymphatic potential ranges from +1 to $+11 \mathrm{mV}$, albeit we note intriguing reports of substantially higher potentials of up to $+70 \mathrm{mV}$ in the cupula of ampullae of the semicircular canals. Similarly, in the auditory system, a high $\left(\mathrm{K}^{+}\right)$is observed. However, in contrast to the vestibular system, the positive endolymphatic potential varies more substantially between vertebrates, ranging from near zero $\mathrm{mV}$ to approximately $+100 \mathrm{mV}$. The tissues generating endolymph in the inner ear show considerable differences in cell types and location. So-called dark cells and the possibly homologous ionocytes in fish appear to be the

Christine Köppl

Cochlea and Auditory Brainstem Physiology, Carl von Ossietzky University Oldenburg Carl-von-Ossietzky Strasse 9-11

DE-26129 Oldenburg (Germany)

E-Mail christine.koeppl@ uni-oldenburg.de

Hans Gerd Nothwang

Department of Neurogenetics, Carl von Ossietzky University Oldenburg

Carl-von-Ossietzky Strasse 9-11

DE-26129 Oldenburg (Germany)

E-Mail hans.g.nothwang@uni-oldenburg.de 
common elements, but there is always at least one additional cell type present. To inspire research in this field, we propose a classification for these cell types and discuss potential evolutionary relationships. Their molecular repertoire is largely unknown and provides further fertile ground for future investigation. Finally, we propose that the ultimate selective pressure for an increased endolymphatic potential, as observed in mammals and to a lesser extent in birds, is specifically to maintain the AC component of the hair-cell receptor potential at high frequencies. In summary, we identify intriguing questions for future directions of research into the molecular and cellular basis of the endolymph in the different compartments of the inner ear. The answers will provide important insights into evolutionary and developmental processes in a sensory organ essential to many species, including humans.

(c) 2018 S. Karger AG, Basel

\section{Introduction}

When von Békésy [1952] explored the fluids of the cochlea in guinea pigs with microelectrodes, he showed that scala media had a positive potential of approximately +80 $\mathrm{mV}$. This potential was termed the endolymphatic or endocochlear potential (EP). The Davis theory, elaborated in a series of classical papers between 1957 and 1965 [Davis, 1957, 1961, 1965] and still prevailing, asserts that the EP and the hair-cell resting potential, coupled in series, together provide the driving force for the transduction process. Consistent with that, any reduction of the EP, as observed by experimental manipulation or by mutations in the underlying molecular repertoire [Nin et al., 2016], results in hearing impairment. For example, in guinea pigs, a $30 \mathrm{mV}$ drop in the EP entails an approximate 60 $\mathrm{dB}$ loss of threshold sensitivity [Manley and Robertson, 1976]. The function of the EP is commonly thought to drive current flow through the hair cell and thus to enhance sensitivity.

Nonmammalian vertebrates show a lower EP, between close to $0 \mathrm{mV}$ and $+35 \mathrm{mV}$. This is closer to the potential observed in the vestibular part of the inner ear, which is typically around $+5 \mathrm{mV}$. Importantly, the ionic composition, i.e., primarily the high $\left(\mathrm{K}^{+}\right)$, is similar in all vertebrates and in both vestibular and cochlear endolymph.

Evolution of the auditory system has seen a major reinterpretation in the last 20 years or so [Clack, 1997; Carr and Soares, 2002; Manley, 2012; Nothwang, 2016]. It is now agreed that the auditory endorgans (amphibian papilla, basilar papilla or organ of Corti) of the different groups of land vertebrates diverged during a long period of independent evolution. From a shared origin, the auditory papilla specialized along different, and sometimes intriguingly convergent lines [Manley and Clack, 2004; Manley, 2017]. It is therefore a timely question to ask whether the mechanisms of endolymph and EP generation are universally shared or not.

The tissue that generates the EP in the auditory compartment of the inner ear is generally assumed to be different between mammals and nonmammalian vertebrates. However, very little is known about the actual mechanisms. The bulk of comparative, i.e., nonmammalian, literature dates from before the 1990s. More recent reviews that touch on comparative or evolutionary aspects of endolymph and EP generation commonly focus on contrasting vestibular and cochlear mechanisms in mammals [e.g., Wangemann 2002; Hibino and Kurachi, 2006; Ciuman, 2009]. This review aims to provide a more comprehensive current summary across the different vertebrate groups, with an emphasis on evolution. We will first review the literature for the lateral line and vestibular systems, assuming they most likely reflect the plesiomorphic condition. This is followed by a summary of the auditory system, separately for the different groups of nonmammalian land vertebrates. Finally, we highlight salient open issues and questions for which modern developmental and genetic approaches offer tools for fruitful investigation.

\section{Endolymph and EP in Different Hair-Cell Endorgans}

\section{Lateral Line}

There Is No Classical Endolymph in the Lateral Line

The fluid bathing the superficial lateral line organs of fish and amphibia and of lateral line organs of fishes with canals that are open to their environment is the same as that of their aqueous environment. Detailed analysis of the ionic composition of the fluid that fills the canals of the open lateral line organs of dogfish revealed that it is not significantly different from that of the surrounding sea water [Liddicoat and Roberts, 1972]. The ionic composition of the aquatic environments inhabited by fish and aquatic amphibia varies enormously and euryhaline fish, such as eels and salmon, can swim between the sea and freshwater rivers, lakes, and ponds. There is evidence that the lateral line system can function in most aquatic environments, but not in environments where there are high levels of divalent cations that block $\mathrm{Ca}^{2+}$ channels, such as Los Angeles tap water [Sand, 1975]. There are 
some species of fish, such as those examined by Smith [1933], where dyes were not able to enter the canal systems. Liddicoat and Roberts [1972] proposed that: "In these fishes there would appear to be two possibilities: the canals could be filled either with a fluid in which the salts were in equilibrium with plasma or with a fluid of special composition." According to measurements by Flock [1965] and Fänge et al. [1972], both possibilities exist in teleost fish. The marine deep-water fish Coryphaenoides rupestris has a lymph-like fluid in its large cranial lateralline canals, similar to that found by Fänge et al. [1972] in two other species of fish with closed canals. In C. rupestris, the ionic composition resembled that of blood plasma, but the $\mathrm{K}^{+}$content was slightly lower. In Lota lota (freshwater burbot), the canal endolymph has a high $\left(\mathrm{K}^{+}\right)$(ten times the blood concentration). In Glyptocephalus cynoglossus, the ionic composition of the canal endolymph resembles sea water. Liddicoat and Roberts [1972] suggested that: "The closing of the canal to the external medium could be regarded therefore as the first stage in the transition to a high-potassium endolymph." Is a high $\left(\mathrm{K}^{+}\right)$, low $\left(\mathrm{Ca}^{2+}\right)$ endolymph essential for hair cell sensory transduction if lateral line organs in different anamniotes are exposed to very different ionic concentrations in their external environments (canal lymph or aquatic environment)? Perhaps the canal lymph in closed systems provides a specialized microenvironment immediately surrounding the hair cells. However, it may be that the ionic composition of this "endolymph" (i.e., the canal lymph or aquatic environment) is not primarily driven by its role in sensory transduction. Instead, the modulation of the physical properties of structures that relay forces to the hair cells may be the more significant (or equally significant) factor.

The Cupula Is Crucial for the Electrical and Ionic Microenvironment of Lateral Line Hair Cells

These considerations, together with evidence from related sense organs, especially the cochlea, that high levels of $\mathrm{K}^{+}$and low, but maintained, levels of $\mathrm{Ca}^{2+}$ in the endolymph [Bosher and Warren, 1978] are important for sensory transduction [reviewed by Fettiplace, 2017], stimulated investigations of the electrochemical environment of mechanosensitive lateral line receptors [Russell and Sellick, 1976; McGlone et al., 1979]. It was hypothesized that a chemical and electrical microenvironment for the lateral line hair cells was provided by the complex, gelatinous cupulae of the lateral line organs.

A schematic of the superficial lateral line neuromast from the tail of the larva of a newt (Triturus cristatus) is



Fig. 1. Schematic cross-sections through lateral line organs. a Schematic cross-section through a superficial lateral line neuromast of the aquatic larval stage of the great crested newt T. cristatus (shown to the right). C, cupula; $\mathrm{H}$, hair cell; $\mathrm{M}$, mantle cell; $\mathrm{P}$, melanin; S, supporting cell. From Russell [1976], reprinted with permission from Springer Nature. b Schematic drawing showing the third supratemporal lateral line canal organ of the lateral line canal system of L. lota (shown below). From Flock [1965], reprinted with permission from Cold Spring Harbor Press.

shown in Figure 1a. The sensory epithelia of superficial and canal lateral line organs are similar in design, with a cluster of pear-shaped sensory hair cells innervated by afferent and efferent fibers and surrounded by supporting cells [Russell, 1976]. A sensory hair bundle comprising a stout kinocilium and a staircase arrangement of stereocilia, with descending order of height determined by the location of the kinocilium, is embedded in the overlying cupula.

The structure and mechanical properties of the cupula are important for coupling the sensory hair cells of the 
Fig. 2. Responses from the double-barrel $\mathrm{K}^{+}$ and $\mathrm{Cl}^{-}$electrodes during insertion into the lateral line cupula of Xenopus. a Diagram of recording arrangement. c, cupula; v, potential electrode; i, ion-selective electrode. b Upper traces: response from ion-selective electrodes ( $\mathrm{K}^{+}$on the left, $\mathrm{Cl}^{-}$on the right). Lower traces: corresponding potential records. Note that the changes in ion concentrations appear simultaneously with a jump to positive potentials, indicating a specialized microenvironment within the cupula. Recordings were obtained from the same animal but in different cupulae. From Russell and Sellick [1976], reprinted with permission from Blackwell Publishing Ltd.

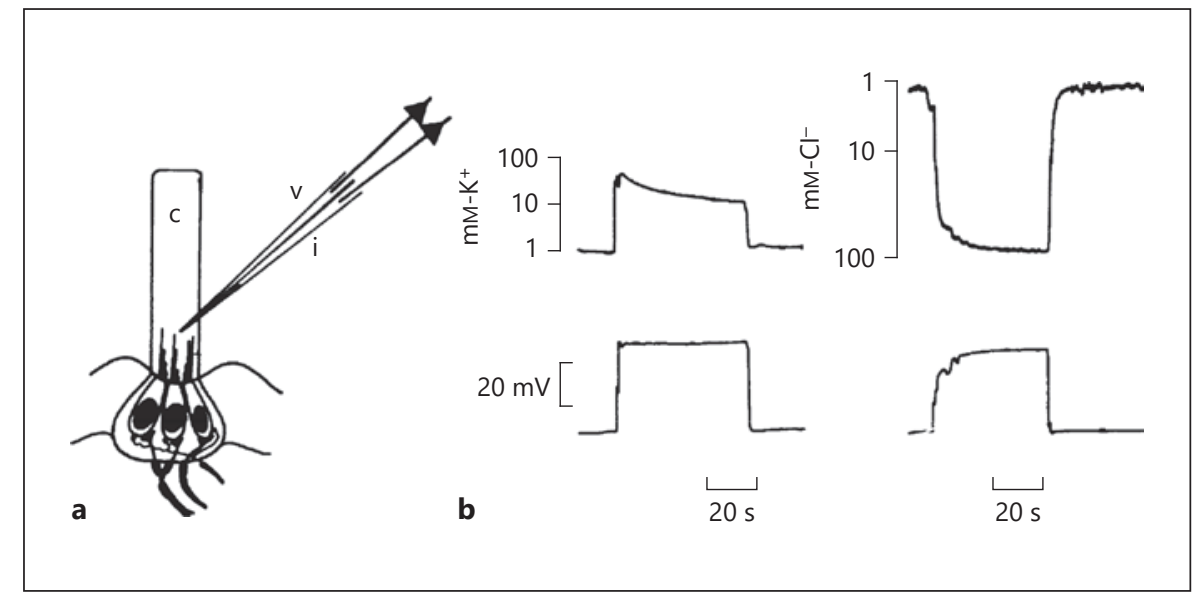

lateral line organs to mechanical disturbances in the environment and are different for canal and superficial organs. The elongated cupula of superficial neuromasts extends into the surrounding water (Fig. 1a) and appears to act as a cantilever beam that bends in the flow [Schulze, 1861; Cahn and Shaw, 1962; Dinklo, 2005]. The flexural stiffness of the cupula should affect how mechanical information is transferred to the mechanosensory hair cells [McHenry and van Netten, 2007]. Canal neuromasts of fishes are recessed into a channel beneath the scales of the head and body (Fig. 1b). Within the channel, the hemispherical cupula behaves as a rigid body that slides along the epithelium when excited by flow [van Netten and Kroese, 1987; Netten and Kroese, 1989].

The proposed microenvironment (equivalent to the endolymph) in such cases would be contained within the physico-chemical structure of the cupula, which is composed of a well hydrated neutral glycosaminoglycan gel [Thomopolous, 1958; Sato, 1962]. The cupulae of some but not all species include extracellular fibrils of unknown composition in the canal, and some superficial neuromasts [Jielof et al., 1952; Flock, 1965; Iwai T., 1967; Müntz, 1989; Kelly and van Netten, 1991]. The central region of the cupula containing the fibrils, when present, is secreted by the supporting cells and the peripheral region of the cupula is secreted by the mantle cells (Fig. 1) [Torroba et al., 1988; Müntz, 1989].

The physical relationship between the cupula and the sensory epithelium is quite different from that of the cochlea. The tectorial membrane is the equivalent "cupula" structure of the cochlea, where only the tips of the tallest row of outer hair cell (OHC) stereocilia are attached to the tectorial membrane, and the hair bundles of inner hair cells (IHCs) are free of any attachment [Lim, 1986].
There is a clear space between the apical reticular membrane surface of the organ of Corti and the underside of the tectorial membrane; hair bundles are therefore in direct contact with the endolymph in the subtectorial space, which may, or may not, have similar ionic composition to that of the endolymph in the greater part of the scala media [Runhaar and Manley, 1987]. In contrast with the cochlea, the base of the cupula of the lateral line organ is closely apposed to the apical surfaces of the hair cells and their surrounding supporting cells and each hair cell stereocilium is completely embedded in the cupula. To test the hypothesis of a specialized microenvironment provided by the cupula to lateral line cells, measurements were made using double barrel ion selective electrodes of $\mathrm{K}^{+}, \mathrm{Cl}^{-}$, and $\mathrm{Ca}^{2+}$ from cupulae of the superficial lateral line neuromasts in the aquatic toad Xenopus laevis (Fig. 2). A positive endocupular potential (ECP) of +15 to $+55 \mathrm{mV}$ was recorded within the cupula, immediately above the hair cells [Russell and Sellick, 1976]. Increases in the $\mathrm{Cl}^{-}$and $\mathrm{K}^{+}$potentials were recorded when the ion selective electrodes touched the cupula. Cupular $\mathrm{Cl}^{-}$and $\mathrm{K}^{+}$varied between $35-70 \mathrm{mM}$ and 24-100 mM, respectively. This variation existed between, rather than within, different animals. From measurements of the resistance of the cupula and the ECP, this variation appeared to be due to variation in the measured cupular resistance, because ECP current flow through the cupula remained almost constant between animals at $17.1 \pm 2.7 \mathrm{nA}$. Subcutaneous injections of the cardiac glycoside ouabain, which inhibits ATP-dependent $\mathrm{Na}^{+}-\mathrm{K}^{+}$ exchange across cell membranes, greatly reduced the ECP and cupular $\mathrm{K}^{+}$. Increasing or decreasing the bath $\mathrm{Cl}^{-}$concentration 100-fold had no effect on the ECP. It was concluded that the ECP was produced by an electro- 
genic $\mathrm{K}^{+}$pump that maintained high $\left(\mathrm{K}^{+}\right)$levels within the cupula. The complex microstructure of the cupula is freely permeable to ions, as revealed by the simultaneous decline of ECP and $\mathrm{K}^{+}$following ouabain injection. $\mathrm{K}^{+}$ diffuses rapidly away from the cupula, so that its levels within the cupula must be quite actively maintained. By contrast, $\mathrm{Ca}^{2+}$ is passively distributed in the cupula [McGlone et al., 1979]. Its concentration $(2-30 \mu \mathrm{M})$ depends entirely predictably on the concentration of $\mathrm{Ca}^{2+}$ in the external milieu and the ECP. The higher the ECP, the lower the $\left(\mathrm{Ca}^{2+}\right)$ in the cupula.

Free-standing neuromasts, therefore, are similar to other sense organs of the acousticolateralis systems in that the apical surfaces of the hair cells are bathed in an electrogenically maintained high $\left(\mathrm{K}^{+}\right)$environment. Measurements have yet to be made to discover if this microenvironment occurs as a consistent feature beneath lateral-line cupulae, or indeed close to the apical surfaces of the various sensory epithelia of vestibular organs.

The Site of Electrogenic Pumping of Potassium in

Lateral Line Organs

The site of the electrogenic pumping of $\mathrm{K}^{+}$into the $\mathrm{cu}-$ pula is unknown, but the ultrastructure of the cupulae [Flock, 1967; Roberts and Ryan, 1971; Jørgensen and Flock, 1973] suggests that this occurs at the mucosal (outer) surface of the supporting cells. Another reason for suggesting that ion transport occurs at the mucosal surface rather than the serosal (inner) surface is that the latter site would necessitate a large intracellular positive potential to provide the electrochemical gradient for $\mathrm{K}^{+}$to then leave passively through channels in the outer membrane. Only negative potentials have been recorded from supporting cells in lateral line organs of Ambystoma [Flock, pers. comm.], Necturus [Sand, 1975], and Lota [Flock et al., 1973].

Melanopsin has been localized to mantle cells or nearby cells that line the edge of the central pore of the lateral line neuromasts in X. laevis [Baker et al., 2015]. Although melanopsin suggests a photoreceptive function and these cells could possibly be involved in modulating lateral-line function [Baker et al., 2015], from their location, they are also potential candidates for the source of the ECP and high $\left(\mathrm{K}^{+}\right)$of the cupula.

\section{Vestibular Inner Ear}

Research on endolymph and EP generation in the vestibular system has largely used mammalian animal models and several recent reviews are available [Hibino and Kurachi, 2006; Ciuman, 2009]. Here, we will focus on what is known about the vestibular system across vertebrates and emphasize consistencies and conflicts with findings in mammals.

Endolymph Composition in the Vestibular System

The composition of vestibular endolymph (in the utricle) was first investigated in the guinea pig. Two reports noted a high $\left(\mathrm{K}^{+}\right)(144 \mathrm{mM})$ and a low $\left(\mathrm{Na}^{+}\right)$concentration (16 mM) [Smith et al., 1954; Citron et al., 1956]. Similar results were subsequently obtained from frogs and birds. In the frog Rana esculenta, determination of ion composition in the ampulla, duct, and utricle revealed similarly high $\left(\mathrm{K}^{+}\right)$and low $\left(\mathrm{Na}^{+}\right)$in all three compartments [Bernard et al., 1986; Ferrary et al., 1992]. Comparison of the ampulla and cochlear endolymphatic $\left(\mathrm{K}^{+}\right)$ in guinea pigs and pigeons showed similar values for both fluids in both species [Ninoyu et al., 1987], which were in the same range as in the guinea pig utricle [Smith et al., 1954]. Finally, Corey and Hudspeth [1983] mentioned unpublished measurements of $260 \mu \mathrm{M}\left(\mathrm{Ca}^{2+}\right)$ in the bullfrog sacculus. This suggests similar conditions in amphibian and mammalian vestibular endolymphs for $\mathrm{Ca}^{2+}$ as well [Wangemann and Schacht, 1996].

Murray and Potts [1961] probed ion concentrations in vestibular endolymph of the ray Raja clavata. They found that $\left(\mathrm{K}^{+}\right)$in (vestibular) endolymph was nineteen times that in perilymph, however, the absolute value was lower $\left(63 \mathrm{mM} \mathrm{K}^{+}\right)$compared to the endolymph of the land vertebrate species summarized above. Furthermore, $\left(\mathrm{Na}^{+}\right)$ was nearly the same in endolymph and perilymph (295 and $281 \mathrm{mM}$, respectively) [Murray, 1960]. Similar results were obtained in skates [Peterson et al., 1978] and toadfish [Ghanem et al., 2008]. $\left(\mathrm{Ca}^{2+}\right)$ concentrations are typically in the range of several $\mathrm{mM}$ in fish endolymph [reviewed by Ghanem et al., 2008].

Thus, vestibular endolymph always shows the characteristic enhanced $\left(\mathrm{K}^{+}\right)$relative to perilymph. However, only in land vertebrates does $\left(\mathrm{K}^{+}\right)$actually exceed $\left(\mathrm{Na}^{+}\right)$, and $\left(\mathrm{Ca}^{2+}\right)$ is maintained below about $1 \mathrm{~mm}$ (Fig. 3a, b).

Magnitude of the EP in the Vestibular System

While $\left(\mathrm{K}^{+}\right)$is high in the vestibular endolymph of all vertebrates, the endolymphatic potential is relatively low. With few exceptions, it ranges from +1 to $+11 \mathrm{mV}$ (Table 1) [Tasaki, 1957; Misrahy et al., 1958; Smith et al., 1958; Schmidt and Fernandez, 1962; Schmidt, 1963b; Ninoyu et al., 1987; Hommerich, 1990]. Tasaki [1957] was the first to presume that the potential in the vestibular endolymph is nowhere near as high as in the mammalian cochlear endolymph. Subsequent studies by Misrahy et al. [1958] 
and Smith et al. [1958] agreed with him, as potentials of not more than $+5 \mathrm{mV}$ in the utricle and of $+1 \mathrm{mV}$ in the saccule were measured [Misrahy et al., 1958; Smith et al., 1958]. Later, Schmidt and Fernandez [1962] obtained



6

Brain Behav Evol 2018:92:1-31 DOI: $10.1159 / 000494050$ measurements in several different nonmammalian species and observed similar values in most cases.

There are a few reports of substantially higher EP in ampullae of the semicircular canals (Table 1). Trincker [1957] measured potentials of +30 to $+40 \mathrm{mV}$ in the guinea pig, and, perhaps most interestingly, found still higher potentials, around $+70 \mathrm{mV}$, at the surface of and inside the cupula, which covers the cristae ampullares. This is reminiscent of the situation in lateral line cupulae (see the above section: The Cupula Is Crucial for the Electrical and Ionic Microenvironment of Lateral Line Hair Cells). In an attempt to determine whether the discrepancy might be due to the use of different kinds of microelectrodes, Dayal [1970] carried out measurements with both metal and glass microelectrodes close to the ampulla of the horizontal semicircular canal of pigeons. He obtained high values with both kinds of electrodes $(+25 \mathrm{mV}$ and $+28.3 \mathrm{mV}$, respectively).

The disparate values obtained for the EP across studies suggest that while an EP close to zero is commonly assumed for vestibular compartments, specialized microenvironments with significantly higher magnitudes may exist immediately around the hair cells. This will be further discussed in a later section (Microenvironments around the Hair Cell Bundles).

\section{Vestibular Tissues Associated with Endolymph \\ Production and Maintenance}

The overall structure of the vestibular part of the inner ear is very similar in all vertebrates, yet the number and shape of sensory endorgans varies. Perhaps the least variation is seen in the semicircular canals, of which there are three (except in jawless vertebrates, i.e., hagfish and lam-

Fig. 3. Comparison of ionic conditions in inner ear fluids and magnitude of EP across different vertebrate groups. Typical values for $\left(\mathrm{Na}^{+}\right),\left(\mathrm{K}^{+}\right)$, and $\left(\mathrm{Ca}^{2+}\right)$ in perilymph $(\mathbf{a})$ and endolymph (b). Different colors identify data from different sources: fish [Ghanem et al., 2008], amphibia (frog) [Corey and Hudspeth, 1983; Bernard et al., 1986], reptiles (pigeon) [Sauer et al., 1999], mammalian vestibular [perilymph: Sterkers et al., 1988; endolymph: Wangemann and Schacht, 1996], and mammalian cochlea [Wangemann, 2006]. Arrows highlight that in fish, endolymphatic $\left(\mathrm{Na}^{+}\right)$is as high as $\left(\mathrm{K}^{+}\right)$, and that endolymphatic $\left(\mathrm{Ca}^{2+}\right)$ varies most drastically between groups. c Median values for EP in different vertebrate groups, shown separately for vestibular and auditory compartments (for sources see Table 1). The color code is the same as in a and $\mathbf{b}$, except that the data for birds are represented separate from the remaining reptiles, by hatched columns. Note that EP values are increased in the auditory compartments of both birds and mammals (arrows), although not to the same extent. 
Table 1. EP measurements

\begin{tabular}{|c|c|c|c|}
\hline $\begin{array}{l}\text { Vestibular } \\
\text { Sacculus } \\
\text { Sacculus } \\
\text { Utriculus } \\
\text { Sacculus, Utriculus } \\
\text { Sacculus } \\
\text { Sacculus } \\
\text { Sacculus } \\
\text { Sacculus } \\
\text { Ampulla } \\
\text { Sacculus } \\
\text { Ampulla } \\
\text { Sacculus } \\
\text { Ampulla } \\
\text { Sacculus } \\
\text { Ampulla } \\
\text { Sacculus } \\
\text { Ampulla } \\
\text { Utriculus } \\
\text { Ampulla, SC } \\
\text { SC } \\
\text { SC } \\
\text { Ampulla } \\
\text { Ampulla } \\
\text { Ampulla, SC } \\
\text { Utriculus } \\
\text { Sacculus }\end{array}$ & $\begin{array}{l}\text { elasmobranch (Scylliorhinus canicula) } \\
\text { teleost (Cottus scorpius) } \\
\text { teleost (Cyprinus carpio) } \\
\text { urodele: mudpuppy (Necturus maculosus) } \\
\text { anuran: leopard frog (Rana pipiens), bullfrog (Rana catesbeiana) } \\
6 \text { turtle species (not differentiated) } \\
\text { painted turtle (Chrysemys picta) } \\
\text { common water snake (Natrix sipedon) } \\
\text { common water snake } \\
\text { garter snake (Thamnophis sirtalis) } \\
\text { garter snake } \\
4 \text { lizard species (not differentiated) } \\
4 \text { lizard species (not differentiated) } \\
\text { horned lizard (Phrynosoma cornutum) } \\
\text { horned lizard } \\
3 \text { Caiman species } \\
3 \text { Caiman species } \\
\text { pigeon, chicken (not differentiated) } \\
\text { pigeon, chicken (not differentiated) } \\
\text { pigeon (Columba livia) } \\
\text { pigeon } \\
\text { pigeon } \\
\text { pigeon } \\
\text { guinea pig (Cavia porcellus) } \\
\text { guinea pig } \\
\text { guinea pig }\end{array}$ & $\begin{array}{l}<+10 \\
+9.75 \\
+6 \\
+3-4 \\
+3 \\
+1 \\
+3.0 \\
+5 \\
+4 \\
+4.1 \\
+7.0 \\
+6 \\
+11 \\
+5.4 \\
+8.0 \\
-0.5 \\
+1 \\
+4 \\
+7,+5 \\
+28.3 \\
+4,+6 \\
+7.4 \\
+7.2 \\
+30-40 \\
+4 \\
+1\end{array}$ & $\begin{array}{l}\text { Murray and Potts [1961] } \\
\text { Enger [1964] } \\
\text { Katsuki et al. [1954] } \\
\text { Schmidt and Fernandez [1962] } \\
\text { Schmidt and Fernandez [1962] } \\
\text { Schmidt and Fernandez [1962] } \\
\text { Schmidt [1963b] } \\
\text { Schmidt and Fernandez [1962] } \\
\text { Schmidt and Fernandez [1962] } \\
\text { Schmidt [1963b] } \\
\text { Schmidt [1963b] } \\
\text { Schmidt and Fernandez [1962] } \\
\text { Schmidt and Fernandez [1962] } \\
\text { Schmidt [1963b] } \\
\text { Schmidt [1963b] } \\
\text { Schmidt and Fernandez [1962] } \\
\text { Schmidt and Fernandez [1962] } \\
\text { Schmidt and Fernandez [1962] } \\
\text { Schmidt and Fernandez [1962] } \\
\text { Dayal [1970] } \\
\text { Schmidt [1963b] } \\
\text { Ninoyu et al. [1987] } \\
\text { Hommerich [1990] } \\
\text { Trincker [1957] } \\
\text { Smith et al. [1958] } \\
\text { Smith et al. [1958] }\end{array}$ \\
\hline $\begin{array}{l}\text { Auditory } \\
\text { Pars basilaris }\end{array}$ & $\begin{array}{l}\text { anuran: leopard frog (Rana pipiens), } \\
\text { bullfrog (Rana catesbeiana) } \\
6 \text { turtle species } \\
\text { painted turtle (Chrysemys picta) } \\
\text { red-eared turtle (Trachemys scripta elegans) } \\
\text { garter snake (Thamnophis sirtalis) } \\
\text { common water snake (Natrix sipedon) } \\
\text { alligator lizard (Gerrhonotus multicarinatus) } \\
4 \text { lizard species (not differentiated) } \\
\text { horned lizard (Phrynosoma cornutum) } \\
3 \text { Caiman species } \\
\text { pigeon, chicken (not differentiated) } \\
\text { pigeon (Columba livia) } \\
\text { pigeon } \\
\text { pigeon } \\
\text { pigeon } \\
\text { pigeon } \\
\text { pigeon } \\
\text { songbirds: starling (Sturnus vulgaris), sparrow (Passer domesticus), } \\
\text { Blackbird (Turdus merula) } \\
\text { chicken (Gallus gallus), P7 } \\
\text { chicken, >P0 } \\
\text { chicken, 2-4 weeks } \\
\text { chicken, >P7 } \\
\text { chicken, >12 weeks } \\
\text { chicken, }>\text { P18 } \\
\text { barn owl (Tyto alba), >P34 } \\
\text { canary (Serinus canaria) } \\
\text { marsupial (Didelphis virginiana) } \\
\text { typical eutherians (rat, guinea pig, mouse, cat) }\end{array}$ & $\begin{array}{l}+3 \\
+2 \\
+3.3 \\
-1.5 \\
+4.6 \\
+7 \\
+16 \\
+7 \\
+7.7 \\
+2 \\
+9 \\
+17 \\
+11 \\
+14.5 \\
+13.8 \\
+10 \text { (approx.) } \\
+8.3 \\
+15 \\
+16.2 \\
+13 \text { (max.) } \\
+11.7 \\
+15.3 \\
+18.1 \\
+14.3 \\
+33.8 \\
+17.6 \\
+89 \\
+80 \text { to }+100\end{array}$ & $\begin{array}{l}\text { Schmidt and Fernandez [1962] } \\
\text { Schmidt and Fernandez [1962] } \\
\text { Schmidt [1963b] } \\
\text { Crawford et al. [1991] } \\
\text { Schmidt [1963b] } \\
\text { Schmidt and Fernandez [1962] } \\
\text { Weiss et al. [1978] } \\
\text { Schmidt and Fernandez [1962] } \\
\text { Schmidt [1963b] } \\
\text { Schmidt and Fernandez [1962] } \\
\text { Schmidt and Fernandez [1962] } \\
\text { Schmidt [1963b] } \\
\text { Jorgensen [1977] } \\
\text { Ninoyu et al. [1987] } \\
\text { Hommerich [1990] } \\
\text { Schermuly et al. [1990] } \\
\text { Sauer et al. [1999]) } \\
\text { Necker [1970] } \\
\text { Cotanche et al. (1987) } \\
\text { Runhaar et al. (1991) } \\
\text { Patuzzi and Bull (1991) } \\
\text { Poje et al. (1995) } \\
\text { Chen et al. (1995) } \\
\text { Wilms et al. (2016) } \\
\text { Wilms et al. (2016) } \\
\text { Gleich et al. (2000) } \\
\text { Schmidt and Fernandez (1962) } \\
\text { review by Fettiplace (2017) }\end{array}$ \\
\hline
\end{tabular}

Measurements of the EP in vestibular (top half) or auditory (lower half) inner ear compartments of different vertebrates. Column 1 specifies the recording location (SC, semicircular canal), and column 2 the animal species. Column 3 lists the mean or median EP value (unless stated otherwise) given by the source listed in column 4 . Note that the list for nonmammalian species is comprehensive to the best of our knowledge, whereas mammalian data were selected to represent typical examples. 
Fig. 4. Schematic drawings of the inner ear of a teleost fish (a) and a mammalian vestibular ampulla (b), with candidate tissues for endolymph production highlighted in different shades of blue. a Drawing of the trout membranous labyrinth; lateral view shown on the top, ventral view of the utricle after removal of the saccule shown below. Filled black patches are the sensory areas, filled blue patches represent areas of ionocytes, the plana semilunata are outlined in light blue. The diagram was redrawn after Becerra and Anadon [1993]. b Schematic drawing illustrating the architecture of the mammalian ampulla in a pseudo-3-dimensional view. The crista, traversing the ampulla, is covered by the sensory hair cells. Their hair bundles protrude into the cupula, which extends to the roof of the ampulla. Planum semilunatum is shown in light blue on the side wall of the ampulla (note that a matching planum would be located on the opposite wall), the transitional zone in a medium shade of blue, at the base of the crista, and the adjacent dark-cell region in dark blue, with its underlying melanocytes. The diagram was redrawn after Lindeman [1969]. CA, crista anterioris; $\mathrm{CH}$, crista horizontalis; $\mathrm{CP}$, crista posterioris; DC, dark cell; $\mathrm{HC}$, hair cell; Me, melanocyte; ML, macula lagenae; $\mathrm{MN}$, macula neglecta; MS, macula saccule; MU, macula utriculi; PS, planum semilunatum; $\mathrm{TZ}$, transitional zone.

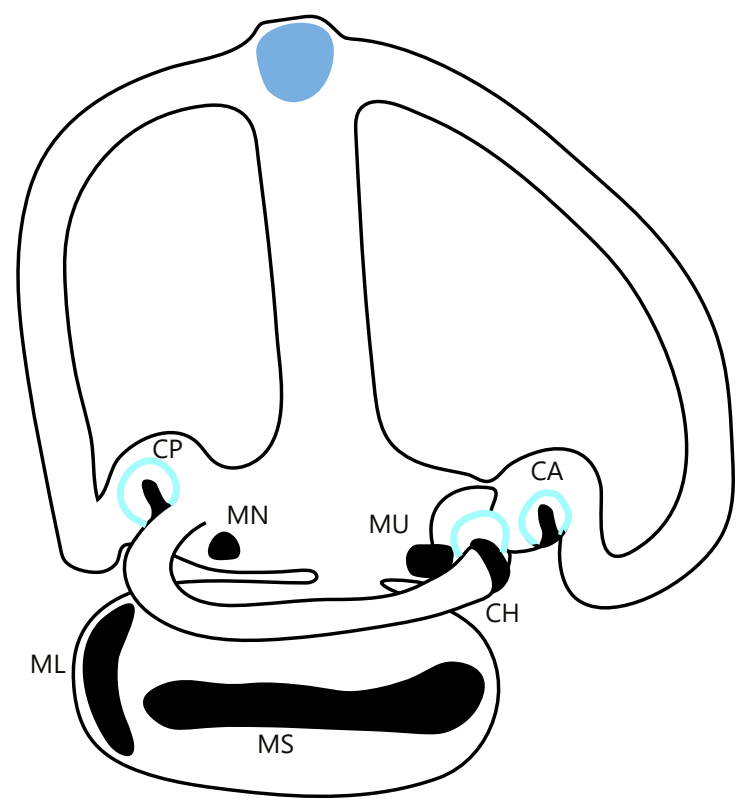

a
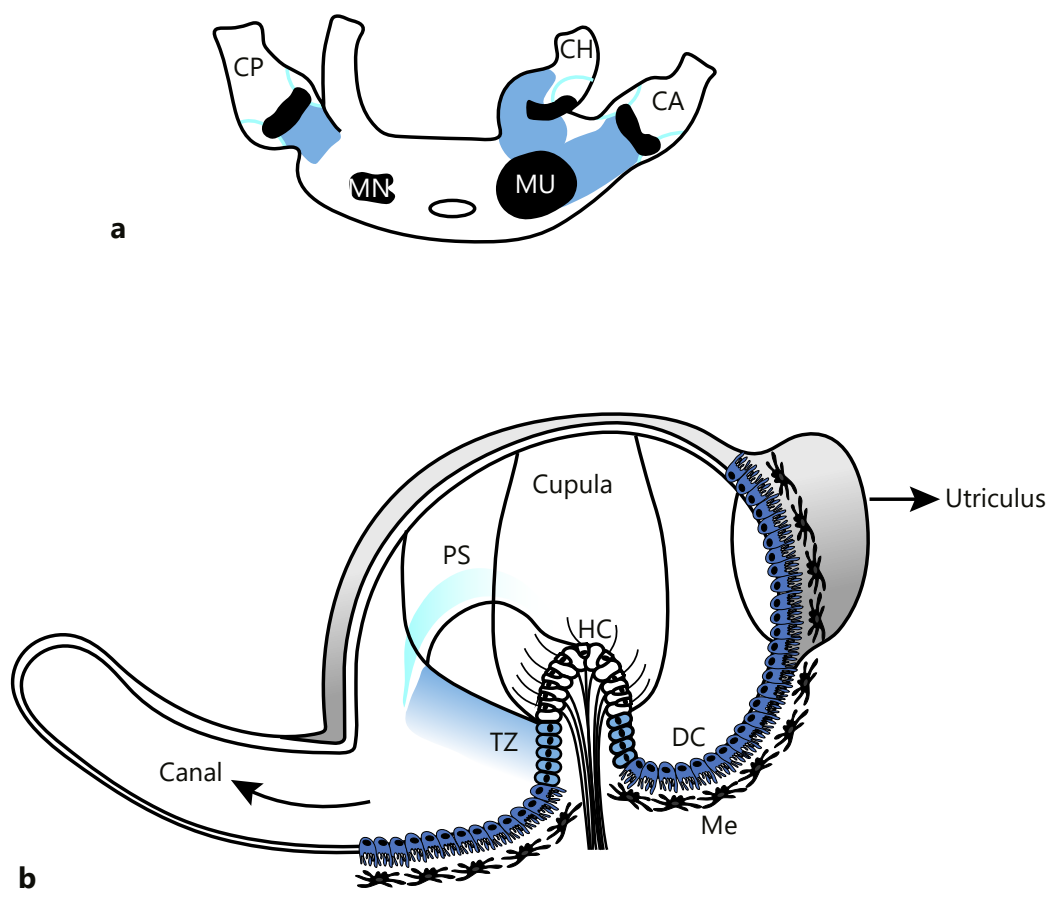

preys). The otolithic endorgans vary more in both number and size [Fritzsch et al., 2002]. We will first summarize evidence for the presence and location of secretory epithelia implicated in endolymph production and then attempt a synthesis of the cell types comprising those epithelia.
Semicircular Canals. Each of the three semicircular canals, two vertical and one horizontal, widens at one end into an ampulla which harbors one sensory organ, the crista ampullaris. Together, the cristae mediate the perception of angular acceleration. Each crista forms a crest 
Fig. 5. Avian dark and light cells. a Schematic three-dimensional drawing of a dark cell and surrounding light cells from the tegmentum vasculosum. Note the basal infoldings of the dark cell plasmalemma and the expanded, microvilli-studded luminal surface of the dark cell which overlaps the edges of the adjacent light cells. From Cotanche and Sulik [1982]. b Scanning electron micrograph (SEM) from the cristaflanking zone in the pigeon. Note the microvilli-studded surfaces of dark cells, surrounded by the slightly folded, bare surfaces of light cells carrying a single kinocilium (kc). c, d SEM images from the tegmentum vasculosum of the pigeon. c shows an overview of several tegmental folds, $\mathbf{d}$ provides a higher-magnification view of several adjacent cells. Again, note the regular arrangement of dark cells surrounded by light cells. b-d from Hommerich [1990]. The original figures did not contain scale bars; $\mathbf{b}$ and $\mathbf{d}$ are scaled comparably.


oriented perpendicular to the plane of the canal (Fig. 4b). The saddle-like top is occupied by the sensory epithelium (crista ampullaris), containing sensory and supporting cells, and covered by a cupula that fills the remaining space towards the roof of the ampulla. This is typically flanked, on one or both sides facing the canals, by an area of epithelium associated with endolymph production and/or maintenance. While this is a universal feature shared by all vertebrates (including lamprey) [Lowenstein et al., 1968], descriptions of the types of cells found there and their spatial arrangement differ significantly between studies on different species. In mammals [Kimura, 1969] and amphibians [Hagmann and Giebel, 1978], a zone of so-called transitional cells flanks the sensory epithelium, followed by so-called dark cells (cell types will be defined and discussed in detail below) situated on the slopes of the crista and adjacent floor regions of the ampulla. The two cell types are thus spatially segregated
(Fig. 4b). In pigeons (presumably typical for birds), dark cells alternate with light cells in the same region (Fig. 5b) [Dohlman, 1965; Ishiyama et al., 1970; Hommerich, 1990; Villegas et al., 2001]. Furthermore, in two of the three ampullae, the transitional zone is greatly enlarged into what has been termed an eminentia cruciata [Hommerich, 1990]. In a teleost fish, the river trout Salmo trutta fario, two types of ionocyte and a cell type termed "associate cells" were found interspersed [Becerra and Anadon, 1993], and these ionocyte areas were only observed on one side of each crista (Fig. 4a).

A further structure of the semicircular canals that is believed to have a role in endolymph- and EP maintenance is found at the transitions from the crista to ampulla wall on either side (Fig. 4). It is half-moon shaped, which inspired its name, planum semilunatum. The planum, too, is consistently found in vertebrates. It is mostly described as an epithelium comprised of a uniform cuboidal cell type 
that is distinct from the cells in the areas flanking the slopes of the cristae [Dohlman, 1964, 1965; Smith, 1970; Hommerich, 1990; ten Cate and Rarey, 1992; Becerra and Anadon, 1993; Villegas et al., 2001]. Some authors identified an additional fringe of transitional cells delineating the planum semilunatum [Becerra and Anadon, 1993; Villegas et al., 2001]. Only in birds were dark cells observed in the planum semilunatum by some authors [Harada et al., 1989, in chicken] but not by others [Hommerich, 1990, in pigeon]. It is unclear whether the planum semilunatum is directly involved in endolymph and EP maintenance. A common - though not universal - observation is an abundance of vesicles and/or granules in the cytoplasm of planum semilunatum cells, which led several authors to suggest that those cells may be involved in secreting the gelatinous substance of the cupula [Dohlman, 1964; Kimura et al., 1964; Munyer and Schulte, 1991]. Other suggestions include a role in water transport [Becerra and Anadon, 1993; Villegas et al., 2001], or even in immunological mechanisms [Ikeda and Morgenstern, 1992].

Finally, the epithelium of the canals themselves has been implicated in ion transport. However, the evidence is inconsistent across vertebrates, suggesting that this is not a shared trait. In a shark, $\mathrm{K}^{+}$-secreting activity was found in the canal ducts and a likely responsible cell type identified. This cell type, which showed salient specializations such as microvilli and basolateral infoldings, is located in a ridge of the canal wall [Garvin et al., 1988]. Importantly, this was different from the condition in frogs, where no $\mathrm{K}^{+}$-transport activity was found in semicircular canals ligated off from the ampulla [Bernard et al., 1986; Ferrary et al., 1992]. In mammals, cells cultured from the semicircular canal ducts of rats were shown to participate in $\mathrm{Na}^{+}$uptake from endolymph [Pondugula et al., 2004, 2006].

Otolithic Organs. Both ends of each semicircular canal join the utricle, which varies greatly in size among vertebrates, and is connected to the saccule via the utriculosaccular duct. Both the utricle and saccule harbor further sensory endorgans, the otolithic maculae, mediating the perception of linear acceleration. In addition to the utricular and saccular maculae, all nonmammals possess a lagenar macula.

Endolymph production and maintenance in those compartments has received less attention than in the semicircular canals. In mammals, transitional cells typically surround both the utricular and saccular maculae [Kawasaki et al., 1992; Kikuchi et al., 1994]. Dark cells, however, were only found in the utricle, in a classic study by Kimura [1969] on guinea pigs (cell types will be de- fined and discussed in detail below). They were located in bands of complex shape that formed a continuum with the dark cell areas of the ampullae and common crus [Kimura, 1969]. A somewhat more restricted, but basically similar, distribution pattern, sparing the saccular compartment, was found for ionocyte areas in the trout inner ear [Becerra and Anadon, 1993] (Fig. 4a). Later studies on several teleosts (trout and turbot) and frogs disagreed on the presence or absence of likely $\mathrm{K}^{+}$-secreting cells in the saccular compartment. Several reports identified ionocytes surrounding the saccular macula in a kind of meshwork [Mayer-Gostan et al., 1997; Takagi, 1997; Pisam et al., 1998]. In addition, Pisam et al. [1998] identified what they termed a "patches area" in the roof of the saccular chamber with cellular morphologies suggestive of secretory activity, but heterogeneous across the different teleost species (trout and turbot). The location of their "patches area" is consistent with what has been termed the "extramacular epithelium" of the sacculus in mammals [Kim and Marcus, 2009].

\section{Cell Types and Mechanisms of Endolymph}

Production and EP Generation

Summarizing the previous section, all vestibular compartments probably contain ion-transporting epithelia of some sort. However, significant differences in their fine structure and location exist and there is no agreed nomenclature across vertebrates. This is particularly true for the cell types of candidate tissues for endolymph production. From the ultrastructural descriptions and the little that is known about specific proteins involved in ion transport in nonmammalian vestibular tissues (Table 2), we tentatively suggest at least three cell types: dark cells, light cells, and transitional cells (Fig. 6). All three (or likely precursors) exist in all vertebrates and may therefore be regarded as plesiomorphic. A categorization into three cell types along similar lines was already suggested by Smith [1970] for the mammalian inner ear.

Dark Cells. Typical dark cells are characterized by extensive intercellular and basal plasma membrane infoldings that are densely packed with mitochondria. It was noted early that these features are also shared with marginal cells of the cochlear stria vascularis, which are responsible for the $\mathrm{K}^{+}$secretion into cochlear endolymph [Kimura, 1964, 1969]. Subsequent studies, mostly in mammals, also revealed functional similarities, including generation of similar transepithelial voltage and resistance and shared ion transport mechanisms using similar control mechanisms [Wangemann, 1995]. Both cell types possess the $\mathrm{Na}^{+} / \mathrm{K}^{+}$ATPase (NKA) and an $\mathrm{Na}^{+} / \mathrm{K}^{+} / \mathrm{Cl}^{-}$ 
Table 2. Molecular repertoire of inner ear ion-transport epithelia in nonmammals

\begin{tabular}{|c|c|c|c|c|}
\hline Species & Molecule & Location & Technique & Reference \\
\hline $\begin{array}{l}\text { Squalus aquanthias } \\
\text { (dogfish shark) }\end{array}$ & NKA & $\begin{array}{l}\text { Basolateral side of semicircular canal } \\
\text { duct epithelium (no cellular } \\
\text { localization) }\end{array}$ & $\begin{array}{l}\text { Isolated semicircular canals in-vitro; } \\
\text { inhibition of fluid secretion by ouabain } \\
\text { treatment }\end{array}$ & Garvin et al. [1988] \\
\hline $\begin{array}{l}\text { Squalus aquanthias } \\
\text { (dogfish shark) }\end{array}$ & NKCC & $\begin{array}{l}\text { Semicircular canal duct epithelium } \\
\text { (no cellular localization) }\end{array}$ & $\begin{array}{l}\text { Isolated semicircular canals in-vitro; } \\
\text { inhibition of fluid secretion and reduction } \\
\text { of }\left(\mathrm{K}^{+}\right) \text {by bumetanide treatment }\end{array}$ & Garvin et al. [1988] \\
\hline $\begin{array}{l}\text { Rana pipiens } \\
\text { (leopard frog) }\end{array}$ & NKA & $\begin{array}{l}\text { Basolateral membrane of dark cells, } \\
\text { utricle and semicircular canals }\end{array}$ & $\begin{array}{l}\text { Quantitative }(3 \mathrm{H}) \text { ouabain } \\
\text { autoradiography; histological localization }\end{array}$ & $\begin{array}{l}\text { Burnham and } \\
\text { Stirling [1984a] }\end{array}$ \\
\hline $\begin{array}{l}\text { Rana pipiens } \\
\text { (leopard frog) }\end{array}$ & NKA & $\begin{array}{l}\text { Basolateral cell membranes, saccule } \\
\text { perimacular, saccule wall }\end{array}$ & $\begin{array}{l}\text { Quantitative }(3 \mathrm{H}) \text { ouabain } \\
\text { autoradiography; histological localization }\end{array}$ & $\begin{array}{l}\text { Burnham and } \\
\text { Stirling [1984b] }\end{array}$ \\
\hline $\begin{array}{l}\text { Rana esculenta } \\
\text { (edible frog) }\end{array}$ & NKA & $\begin{array}{l}\text { Basolateral side of semicircular canal } \\
\text { ampullae (no cellular localization) }\end{array}$ & $\begin{array}{l}\text { Isolated semicircular canal in vitro; } \\
\text { ouabain bath application: decrease of } \\
\left(\mathrm{K}^{+}\right) \text {, increase of }\left(\mathrm{Na}^{+}\right) \text {, EP abolished, in } \\
\text { canal lumen }\end{array}$ & Ferrary et al. [1992] \\
\hline $\begin{array}{l}\text { Rana esculenta } \\
\text { (edible frog) }\end{array}$ & NKCC & $\begin{array}{l}\text { Basolateral side of semicircular canal } \\
\text { ampullae (no cellular localization) }\end{array}$ & $\begin{array}{l}\text { Isolated semicircular canal in-vitro; } \\
\text { furosemide or bumetanide bath } \\
\text { application: decrease of }\left(\mathrm{K}^{+}\right) \text {, increase of } \\
\left(\mathrm{Na}^{+}\right) \text {, EP abolished, in canal lumen }\end{array}$ & Ferrary et al. [1992] \\
\hline $\begin{array}{l}\text { Rana esculenta } \\
\text { (edible frog) }\end{array}$ & $\mathrm{ENaC}$ & $\begin{array}{l}\text { Luminal side of semicircular canal } \\
\text { ampullae (no cellular localization) }\end{array}$ & $\begin{array}{l}\text { Isolated semicircular canal in vitro; } \\
\text { amiloride luminal application: decrease of } \\
\left(\mathrm{K}^{+}\right) \text {, increase of }\left(\mathrm{Na}^{+}\right) \text {in canal lumen; no } \\
\text { effect on EP }\end{array}$ & Ferrary et al. [1992] \\
\hline Gallus gallus (chicken) & NKA & Tegmentum vasculosum & In situ hybridization on cryosections & Wilms et al. [2016] \\
\hline Gallus gallus (chicken) & NKCC1 & Tegmentum vasculosum & In situ hybridization on cryosections & Wilms et al. [2016] \\
\hline Gallus gallus (chicken) & BSND & Tegmentum vasculosum & In situ hybridization on cryosections & Wilms et al. [2016] \\
\hline Gallus gallus (chicken) & CLCK & Tegmentum vasculosum & In situ hybridization on cryosections & Wilms et al. [2016] \\
\hline Gallus gallus (chicken) ${ }^{1}$ & KCNJ10 & Not found & In situ hybridization on cryosections & Wilms et al. [2016] \\
\hline Gallus gallus (chicken) ${ }^{1}$ & KCNJ16 & Not found & In situ hybridization on cryosections & Wilms et al. [2016] \\
\hline Gallus gallus (chicken) & KCNQ1 & Tegmentum vasculosum & In situ hybridization on cryosections & Wilms et al. [2016] \\
\hline Gallus gallus (chicken) & KCNE1 & Tegmentum vasculosum & In situ hybridization on cryosections & Wilms et al. [2016] \\
\hline Columba livia (pigeon) & NKA & Cochlear duct & $\begin{array}{l}\text { Ouabain application to perilymph in vivo: } \\
\text { EP went negative }\end{array}$ & Ninoyu et al. [1987] \\
\hline Columba livia (pigeon) & NKA & Ampulla & $\begin{array}{l}\text { Ouabain application to perilymph in vivo: } \\
\text { EP went negative }\end{array}$ & Ninoyu et al. [1987] \\
\hline
\end{tabular}


Table 2 (continued)

\begin{tabular}{lllll}
\hline Species & Molecule & Location & Technique & Reference \\
\hline Columba livia (pigeon) & NKCC & Cochlear duct & $\begin{array}{l}\text { Application of ethacrynic acid to } \\
\text { perilymph in vivo: EP went negative }\end{array}$ \\
\hline Columba livia (pigeon) & NKCC & Ampulla & $\begin{array}{l}\text { Application of ethacrynic acid to } \\
\text { perilymph in vivo: EP went negative }\end{array}$ \\
\hline Columba livia (pigeon) & NKCC & Cochlear duct & Cochlear duct & $\begin{array}{l}\text { Systemic application of ethacrynic acid: } \\
\text { no effect on EP in vivo }\end{array}$ \\
\hline Columba livia (pigeon) ${ }^{1}$ & NKCC & $\begin{array}{l}\text { Systemic application of furosemide: no et al. [1987] } \\
\text { effect on EP in vivo }\end{array}$ & Schermuly et al. [1990] \\
\hline Anas platyrhynchos (duck) & NKA & $\begin{array}{l}\text { Dark cells of tegmentum } \\
\text { vasculosum }\end{array}$ & $\begin{array}{l}\text { Na }{ }^{+} / \mathrm{K}^{+} \text {ATPase activity label on ultrathin } \\
\text { tissue sections }\end{array}$ & Hossler et al. [2002a] \\
\hline
\end{tabular}

Molecular repertoire of inner ear ion-transport epithelia in nonmammals. Column 1 specifies the animal species, column 2 the gene or protein investigated, and column 3 the precise location where it was observed within the inner ear. Column 4 summarizes the technique that was used and column 5 lists the source.

${ }^{1}$ These studies reported negative results.

cotransporter (NKCC) in the basolateral membrane, to take up $\mathrm{K}^{+}$. $\mathrm{Cl}^{-}$circulates back through the chloride channel CLC-K. In the apical membrane, KCNQ1 releases $\mathrm{K}^{+}$ into endolymph [Wangemann, 1995; Ciuman, 2009]. Together, these similarities with marginal cells have led to the general acceptance that dark cells are responsible for $\mathrm{K}^{+}$secretion in the vestibular system.

For nonmammals, the data are sketchier and derive primarily from experiments applying appropriate blockers. There is good evidence for the involvement of NKA and NKCC, but NKCC has not yet been strictly localized to dark cells, and NKA only in frogs (Table 2). In the fish literature, the term dark cell is not used. However, the socalled typical ionocytes of the teleost vestibular system are clearly the equivalent, and possibly the homologs, of dark cells. Ionocytes share salient properties with dark cells, such as a high density of mitochondria and vacuoles suggestive of a secretory function [Becerra and Anadon, 1993], apical microvilli [Dohlman, 1964; Harada et al., 1989; Hommerich, 1990; Becerra and Anadon, 1993] and an absence of gap junctions [Becerra and Anadon, 1993; Kikuchi et al., 1994; Villegas et al., 2001]. Ionocytes differ from dark cells primarily by having a smooth basal surface. They are, however, characterized by extensive intracellular tubular and cisternal membrane systems that are probably functionally similar to the basal membrane infoldings of dark cells (Fig. 7) [Becerra and Anadon, 1993]. To our knowledge, ionocytes of the teleost inner ear have not been tested for the presence of NKA or NKCC; however, ionocytes of the teleost gill are well known to express both [Takei et al., 2014].
Transitional Cells. In mammals, transitional cells are typically observed fringing all vestibular sensory epithelia [Kawasaki et al., 1992; Lee et al., 2001; Kim and Marcus, 2011]. In nonmammals, the term transitional cell has only been used for cells fringing the planum semilunatum [Villegas et al., 2001]. We suggest that what has been termed pale ionocytes [Becerra and Anadon, 1993] and saccular perimacular meshwork [Takagi, 1997; Pisam et al., 1998] are the same cell type (Fig. 6). These cells also show moderate NKA activity [Burnham and Stirling, 1984b; Kawasaki et al., 1992; Takagi, 1997], which may explain conflicting results regarding the presence or absence of "dark cells" in the saccular compartment, based on NKA activity assays. Indeed, Burnham and Stirling [1984a] and Kawasaki et al. [1992] showed by direct quantitative comparisons within the same species - frog and rat, respectively - that the NKA activity of transitional cells is about one order of magnitude below that of typical dark cells. Transitional cells are likely also characterized by gap junctions between each other [Kikuchi et al., 1994], lateral membrane infoldings [Smith, 1970], and apical microvilli [Smith, 1970; Takagi, 1997]. In mammals, transitional cells have been shown to express a large, as yet uncharacterized, $\mathrm{K}^{+}$conductance, a minor $\mathrm{Cl}^{-}$conductance [Wangemann and Marcus, 1989], and KCNK channels [Popper et al., 2008], in addition to NKA and NKCC [Bartolami et al., 2011].

Light Cells. We include the cells of the planum semilunatum and the so-called associate cells of the teleost inner ear [Becerra and Anadon, 1993] in this light cell type (Fig. 6). Light cells have so far been characterized entirely
Köppl/Wilms/Russell/Nothwang 
Fig. 6. Tabular overview of the cell type classification suggested in this review. The top row contains pictograms representing, from left to right: the lateral line, vestibular inner ear, avian auditory compartment, and mammalian cochlea. The left-most column shows pictograms representing the principal cells types, from top to bottom: dark cell, transitional cell, light cell, melanocyte. The remaining fields list the different terms used for these cell types in different vertebrate groups and inner ear endorgans (for references and details, see text).

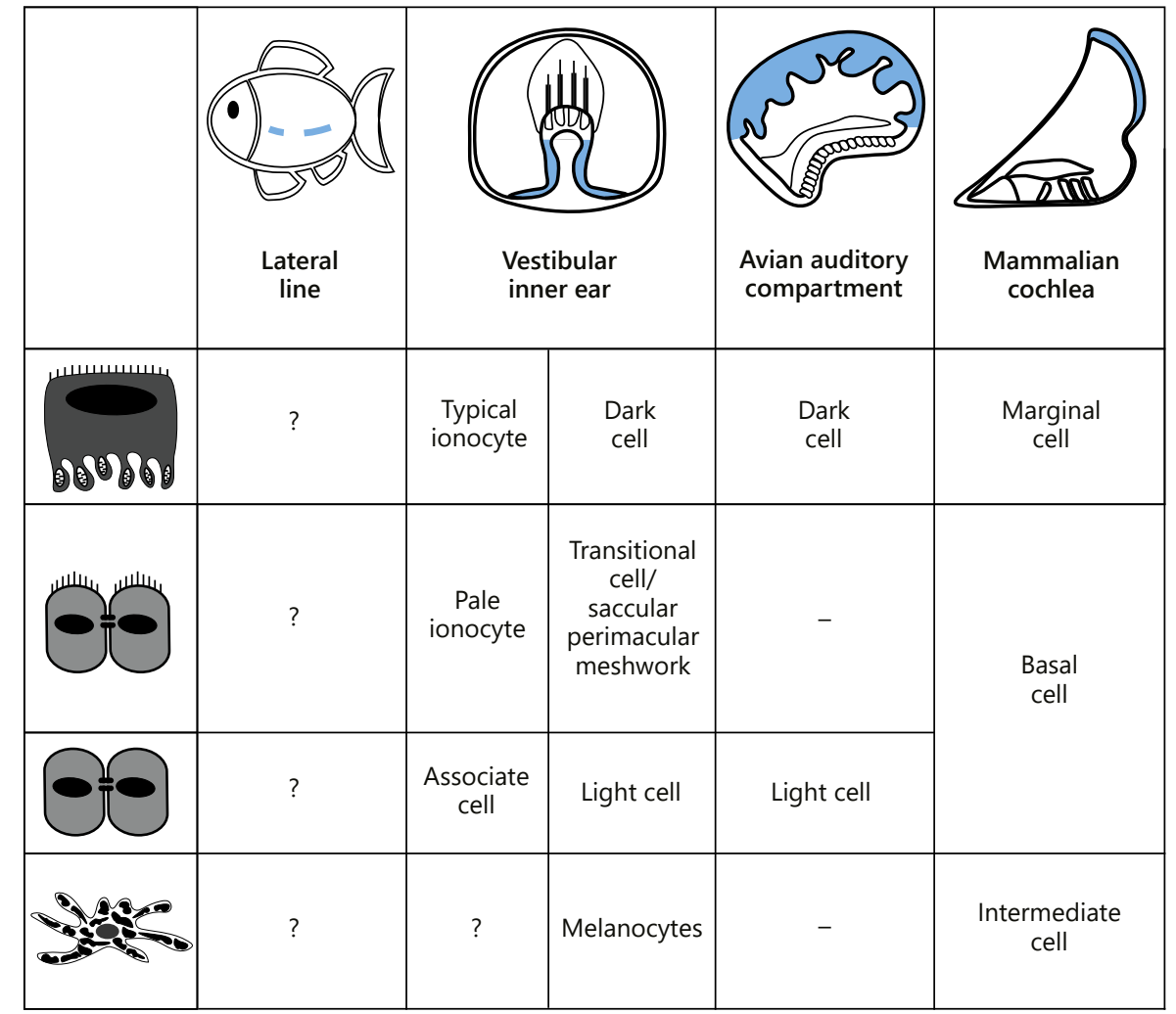

on the basis of their morphology. We suggest that they are distinguished by an absence of apical microvilli [Dohlman, 1964; Harada et al., 1989; Hommerich, 1990; ten Cate and Rarey, 1992; Becerra and Anadon, 1993]. They are further characterized by a pale cytoplasm that inspired their name, and prominent gap junction connections [Becerra and Anadon, 1993; Kikuchi et al., 1994; Villegas et al., 2001; Helling and Merker, 2005]. Membrane projections or interdigitations with neighboring cells are also commonly observed [Dohlman, 1964; Kimura et al., 1964; Harada et al., 1989; ten Cate and Rarey, 1992]. Light cells may show low NKA activity [Kawasaki et al., 1992].

Extramacular and Semicircular Canal Duct Cells. A possible fourth cell consists of the extramacular and semicircular canal duct cells that, in mammals, are distinguished from transitional cells by the presence of $\mathrm{ENaC}$ channels [Kim and Marcus, 2011]. Consistent with that idea, an amiloride-sensitive $\mathrm{Na}^{+}$conductance (suggesting $\mathrm{ENaC}$ ) was also observed in the luminal membranes of semicircular canal duct cells in the frog [Ferrary et al., 1992]. By location, the semicircular canal duct cells of the shark [Garvin et al., 1988] and the cells in the "patches area" of the teleost sacculus [Pisam et al., 1998] may also

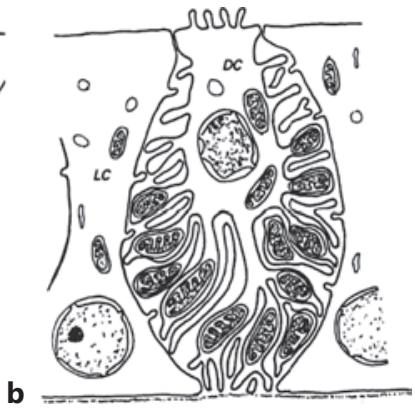

Fig. 7. Schematic drawings comparing teleost ionocytes and dark cells. a A trout ionocyte (IC), flanked by associate cells (AC). b A dark cell (DC) from the avian tegmentum vasculosum, flanked by light cells (LC). From Becerra and Anadon [1993], reprinted with permission from John Wiley and Sons Inc.

fall into this group. However, in the shark, there was clear evidence for NKA and NKCC activity in the ducts [Garvin et al., 1988], which, to our knowledge, has never been observed in this cell type in mammals. Clearly, many open questions remain regarding the classification of cell types 


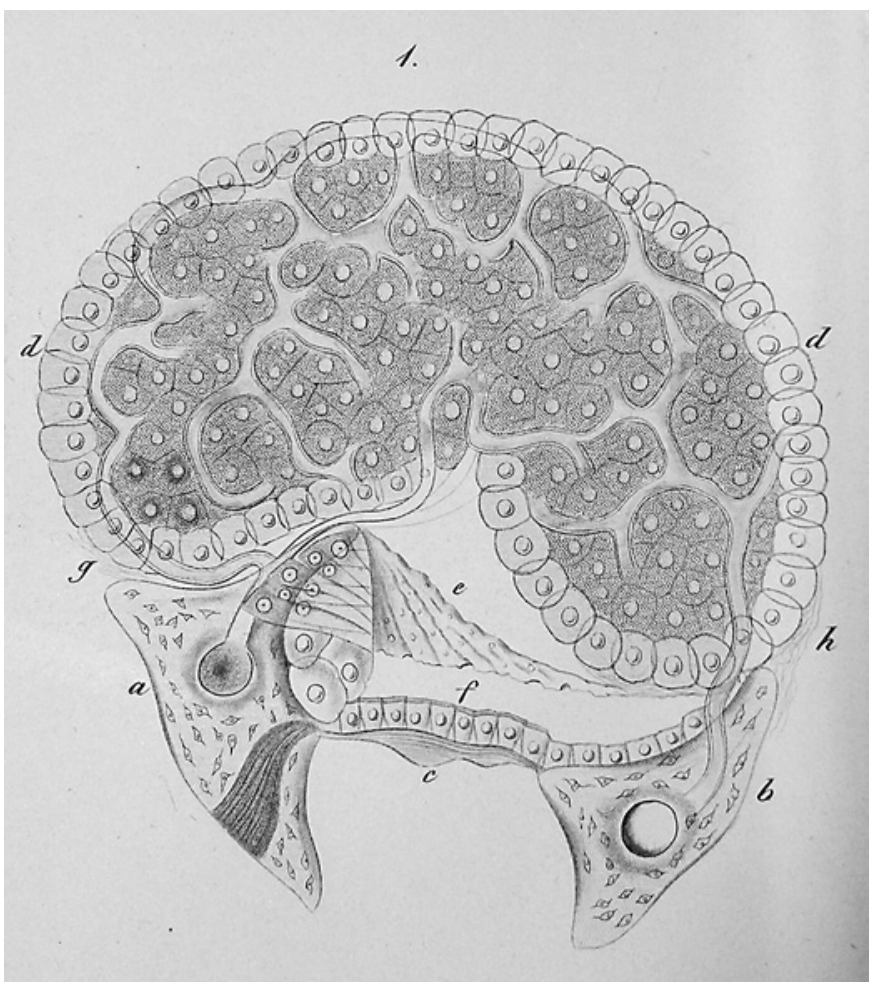

Fig. 8. Historical illustration by Deiters [1860], who introduced the term tegmentum vasculosum (translations into modern English terms by C.K.). Drawing of a cross-section of the avian cochlear duct, approximately half-way along. Neural limbus (a), abneural limbus (b), basilar membrane (c), tegmentum vasculosum (d), tectorial membrane (e), hair cells (f); $\mathbf{g}$ and $\mathbf{h}$ were not explained.

and their relative roles in the vestibular secretory epithelia.

Melanocytes in the Vestibular System. There is one additional cell type - melanocytes - whose distribution tightly correlates with that of dark cells. Throughout the membranous wall of the vestibular system, melanocytes form a layer underneath the epithelial lining of dark cells and are also in close proximity to blood vessels [Kimura et al., 1964; Meyer zum Gottesberge, 1988a, b]. They were sometimes even observed to invade between the basal infoldings of secretory dark cells [Kimura et al., 1964], perhaps triggered by stress conditions such as experimentally induced endolymphatic hydrops [Meyer zum Gottesberge, 1988a, b]. Despite this seemingly intimate relationship with dark cells, the function of melanocytes in the vestibular system remains obscure. They have been suggested to indirectly protect the sensory hair cells from damage, due to their capacity to trap ototoxic drugs or free radicals [Meyer zum Gottesberge, 1988a, b; Tachiba- na, 1999]. There is no evidence for their involvement in endolymph and/or EP production. This is different in the mammalian cochlea, where neural crest-derived melanocytes form the intermediate cells of the stria vascularis (Fig. 6; see also Mammalian Cochlea, below). However, a protective function may persist, as suggested by inverse correlations between the degree of pigmentation and the degree of noise-induced hearing loss [Meyer zum Gottesberge, 1988a, b; Tachibana, 1999].

\section{Amphibian Auditory Inner Ear}

Endolymph Composition and EP in the Amphibian Auditory System

To our knowledge, endolymph composition has not been probed specifically in the auditory parts of the amphibian inner ear, i.e., amphibian papilla and basilar papilla. However, these auditory compartments are small and in close connection to the other endolymph spaces of the inner ear [Mason et al., 2015]; therefore, the distinction between vestibular and auditory endolymph is probably not useful and we may assume uniform conditions throughout. There is one specific measurement of EP in the basilar-papilla compartment of the leopard frog inner ear [Schmidt and Fernandez, 1962] (Table 1) which, at +3 $\mathrm{mV}$, further supports this assumption.

\section{The Tegmentum Vasculosum, as Defined by Early}

\section{Anatomists}

In amphibians, the structure that is likely to be responsible for secreting endolymph and maintaining the EP is called the tegmentum vasculosum. The term was introduced by Deiters [1860] to highlight two characteristics revealed by a closer examination of the structure, initially in birds (Fig. 8): (i) its location above the sensory epithelium (Latin: tegere, "to cover") and (ii) its extreme vascularization. He felt this term more apt than the previously used "membrana vasculosa" or "hearing sheets" (Gehörblätter) [Treviranus, 1924], as its extensive vascularization and complex structure was not that of a simple membrane. Deiters recognized it as a rich epithelium consisting of blood vessels and two different cell types: (i) large cells constituting the bulk of the inner tissue with a polygonal contour and a dark granular but nonpigmented structure, (ii) small cylindrical epithelial cells. These cell types correspond to the subsequently introduced terms dark and light cells, respectively. Deiters [1860] referred to the marginal cells of the stria vascularis as the only cells known to him as being similar to the polygonal cells of the tegmentum vasculosum. Indeed, he already clearly drew the analogy to the mammalian stria vascularis. Concern- 
ing the function of the tegmentum vasculosum, Deiters speculated that it serves as an apparatus to enlarge the capillary system.

In a subsequent study, Deiters applied this term to what he felt was the corresponding structure in frogs. In Batrachia (a clade of amphibians that includes frogs and salamanders), he observed a highly vascularized area with grainy, large cells that he considered to be the analogue (German: analogon) to the avian and reptilian tegmentum vasculosum. He had some reservations, because lagena and limbic support tissue are almost completely separated in frogs, which means that they do not form a rooflike covering (tegmentum). The tegmentum vasculosum mainly forms the lateral roof of the upper part of the sacculus [Kuhn, 1880; Gaupp, 1896].

In a study on a broad range of species (Cyclostomata, Ganoidei, Teleostei, Elasmobranchii, Dipnoi, and Amphibia), Retzius [1881] subsequently described a tegmentum vasculosum only in anurans, where he found it prominently developed in Bufo vulgaris, Hyla arborea, and Pelobates fuscus, very poorly developed in Alytes obstetricans and almost absent in R. esculenta. In the cyclostomes and all the fish species investigated, as well as in urodeles, he only observed a single-layered, simple epithelium [Retzius, 1881]. Additional studies in other amphibians reported its lack in primitive species such as Ascaphus or Leiopelma [Wagner, 1934] and in pipids including Xenopus [Paterson, 1960; Mason et al., 2015]. In general, the tegmentum vasculosum is found in all neobatrachian ears investigated so far [Mason et al., 2015], whereas it is absent or very poorly developed in archaeoand mesobatrachians. The underlying reason for this variability is unknown. Ascaphus or Leiopelma are characterized by the absence of the middle ear [Wagner, 1934, 1934,1935 ], but this is not the case for X. laevis [Mason et al., 2015].

Retzius [1981], as well as Kuhn [1880] and Hasse [1868], described the cells in the anuran tegmentum vasculosum as yellowish pigmented, heavily granulated cells. Hasse [1868] reported more explicitly a gradual change from normal epithelial cells to more granulated cells. Both Hasse [1873] and Kuhn [1880] noted the similarity to pigmented cells close to the cristae at the floor of the ampulla of fish (primarily teleosts) and amphibia. These cells showed an irregular distribution in fish, whereas they formed yellowish round patches in frogs [Hasse, 1873; Kuhn, 1880]. Hasse [1873] did not observe these cells in the ampulla of other vertebrates. Unfortunately, this was never followed up in more detail and it remains unclear whether the cells correspond to dark cells. In gen-

Evolution of the Inner Ear Endolymphatic System eral, the definition of the amphibian tegmentum vasculosum therefore remains vague and warrants further investigation.

\section{Mechanisms of Endolymph Production and EP}

Generation

To our knowledge, the mechanisms of endolymph production and EP generation in the auditory compartments of the inner ear have only been addressed in birds of all nonmammals (see the next section on reptiles).

\section{Auditory Inner Ear of Birds and Other Reptiles}

Note that the term "reptiles" is used here for convenience. We are aware that it is not a taxonomic term anymore, as it groups together a polyphyletic collection of animals. Birds and crocodilians together belong to the Archosaurs [Brusatte et al., 2015], lizards, snakes, and the tuataras of New Zealand to the Lepidosaurs [Vidal and Hedges, 2009], and the assignment of turtles continues to be controversial [Joyce, 2015].

\section{Endolymph Composition}

The ionic composition of auditory endolymph has barely been explored for nonavian reptiles. Early studies included turtles and lizards and worked with fluid samples that often exceeded the total endolymphatic volume and thus faced serious contamination issues [Johnstone et al., 1963; Peterson et al., 1978]. The topic has scarcely been revisited since. There is an anecdotal reference to measurements of $160 \mathrm{mM}\left(\mathrm{K}^{+}\right)$with ion-selective electrodes in a lizard species, [see Discussion section of Runhaar et al., 1991]. The only ion that was explored in some more depth is $\mathrm{Ca}^{2+}$, mostly in the context of its role for hair-cell transduction. Estimates for $\left(\mathrm{Ca}^{2+}\right)$ vary widely, between $>1 \mathrm{~mm}$ in lizards [Manley et al., 2004] to as low as around $60 \mu \mathrm{M}$ in turtles [Crawford et al., 1991; Ricci et al., 1998; Farris et al., 2006].

For birds, auditory endolymph composition has been reasonably well established and is basically the same as in mammals, except for higher $\left(\mathrm{Ca}^{2+}\right)$. The most comprehensive measurements are those of Sauer et al. [1999] in the pigeon, who used ion-selective electrodes to determine concentrations of $141 \mathrm{mM}\left(\mathrm{K}^{+}\right), 142 \mathrm{mM}\left(\mathrm{Cl}^{-}\right)$, and $0.23 \mathrm{mM}\left(\mathrm{Ca}^{2+}\right) ;\left(\mathrm{Na}^{+}\right)$was not determined (Fig. 3b). Similar results were obtained for $\left(\mathrm{K}^{+}\right)$in chickens [Runhaar et al., 1991].

\section{Magnitude of the EP}

The classic comparative studies of Schmidt and colleagues [Schmidt and Fernandez, 1962; Schmidt, 1963b] 
found that the EP in the auditory part of the inner ear (cochlear/lagenar compartment) showed consistently lower values in the ectothermic reptiles, compared to the endothermic birds. For birds, this has since been amply confirmed, with typical values around $+15 \mathrm{mV}$ (Table 1; Fig. 3c). Lizards, turtles, and crocodilians have hardly been revisited; reported values typically fall below +10 $\mathrm{mV}$ (Table 1). An interesting exception among birds is the barn owl, where a significantly higher median EP of +34 mV was found [Wilms et al., 2016]. A correlation with extended high-frequency sensitivity was suggested (see also Role of the EP), but it remains unknown what enables the barn owl to maintain this higher EP.

A curious finding was the lack of any hypoxia sensitivity of the EP in all ectothermic species: turtles, snakes, lizards, and even crocodiles [Schmidt and Fernandez, 1962; Schmidt, 1963a, b]. We feel it is unlikely that this truly suggests the absence of any electrogenic component to the EP in those species. Rather, it may reflect generally lower metabolic rates and a concomitant enhanced physiological robustness to short-term changes. For the redeared turtle Trachemys scripta elegans it is known that an isolated half-head preparation shows sensitive auditory responses for many hours [Art and Fettiplace, 1984].

\section{The Tegmentum Vasculosum of Birds}

In one of the earliest descriptions of the avian tegmentum vasculosum, Deiters [1860] (Fig. 8) already identified a light and dark cell type, although he did not use those terms. Similarly, Satoh [1917], who worked with semithin sections of beautifully preserved tissue, as well as Krause [1922], distinguished light and dark cells but used different terms. The terms "light" and "dark" cells then became common with the early electron microscopic studies and referred to their appearance as osmiophobic and osmiophilic (electron dense), respectively [Jahnke et al., 1969; Ishiyama et al., 1970]. A very characteristic feature of the avian tegmentum vasculosum are its lamellae or folds, which may penetrate deep into the scala media and represent a significant expansion of its endolymphatic surface.

The analogy between the avian tegmentum vasculosum and the mammalian stria vascularis was recognized very early, based on morphology. Evidence that the tegmentum vasculosum is indeed responsible for endolymph production and generation of the EP has since accumulated from several lines of investigation. The tegmentum vasculosum has been shown to have a similar level of NKA activity as the mammalian stria vascularis [Kuijpers et al., 1970]. The developmental time course of tegmentum vasculosum structural maturation, increase in NKA activity, and gradual increase in endolymphatic $\left(\mathrm{K}^{+}\right)$and EP are tightly correlated with one another [Cotanche and Sulik, 1982; Cotanche et al., 1987; Schneider et al., 1987; Runhaar et al., 1991].

Light and dark cells of the avian tegmentum vasculosum are arranged alternating in a mosaic or checkerboard pattern (Fig. 5a, c, d) [Held, 1926; Ishiyama et al., 1970; Cotanche and Sulik, 1982; Hossler et al., 2002b]. The epithelium was characterized as single-layered in some classic early studies [Held, 1926; Ishiyama et al., 1970] and this is now commonly assumed. However, the pronounced folding of the epithelium makes it difficult to define an unambiguous cross-sectional plane and, as pointed out by Hossler et al. [2002b], it is difficult to be sure that it really is a single layer throughout. Another practical problem is the identification of the two cell types. While light and dark cells are readily distinguished in electron-microscopic preparations [Ishiyama et al., 1970; Hirokawa, 1980; Cotanche and Sulik, 1982; Cotanche et al., 1987; Yoshihara et al., 1990; Hossler et al., 2002b], light cells are difficult to identify in light-microscopic sections [Schneider et al., 1987; Wilms et al., 2016] and no specific marker for them is currently known.

The many morphological similarities between dark cells of the tegmentum vasculosum and dark cells in the vestibular system, as well as marginal cells of the stria vascularis, have been pointed out many times. Most importantly, they share the characteristic folding of their cell membranes and the dense packing with mitochondria [Jahnke et al., 1969; Ishiyama et al., 1970; Rosenhall, 1971; Cotanche and Sulik, 1982; Cotanche et al., 1987; Hara et al., 2002; Hossler et al., 2002b]. Furthermore, their function and the molecular mechanisms underlying this function are shared (see the next section on Mechanisms of Endolymph Production and EP Generation). However, there are also subtle differences, the significance of which remains poorly understood. In contrast to strial marginal cells, dark cells of the avian tegmentum vasculosum have a characteristically constricted apical neck region (Fig. 5a) [Ishiyama et al., 1970; Rosenhall, 1971; Hirokawa, 1980; Cotanche and Sulik, 1982; Hossler et al., 2002b]. They are also not in close contact with blood capillaries. As first pointed out by Ishiyama [1970], a basement membrane separates both light and dark cells from connective tissue and blood vessels. Furthermore, as a rule [Hossler et al., 2002], only the light cells extend to that level and thus act additionally to separate the dark cells from the capillaries [Ishiyama et al., 1970; Hossler et al., 2002b].
Köppl/Wilms/Russell/Nothwang 
The role of the light cells in the tegmentum vasculosum is basically unknown. Ishiyama et al. [1970] saw salient structural similarities to secretory cells in other systems and speculated that light cells maintain the endolymph fluid balance by secreting water back into the scala media. To our knowledge, this has never been tested. Light cells are coupled to each other via gap junctions [Hirokawa, 1980; Hossler et al., 2002b], which may be reminiscent of the extensive gap-junctional network between intermediate and basal cells of the mammalian stria vascularis. However, in contrast to intermediate and basal cells, the light cells of the avian tegmentum vasculosum, like the dark cells, face endolymph.

The Tegmentum Vasculosum of Nonavian Reptiles

Next to nothing is known about the site of endolymph and EP production in turtles, lizards, and snakes. As discussed above, Deiters [1862], guided by his initial studies in birds, also identified a tegmentum vasculosum in lizards, albeit thinner and unfolded. Similar to the avian tegmentum vasculosum, he identified a layer of small cylindric epithelial cells, followed by grainy, loosely packed polygonal cells that were fewer in number than the epithelial cells. Other early investigators reported no particular specializations and did not use the term tegmentum vasculosum [Clason, 1873; Hasse, 1873; Retzius, 1884], although Clason [1873] concluded homology of his membrana reissneri in lizards and the avian tegmentum. Much later, Weiss et al. [1978], citing the PhD thesis of Mulroy [1968], reported that "dark cells, whose structure is similar to those found in the mammalian inner ear, are found in the endolymphatic surface of the vestibular membrane in lizards." To our knowledge, this was never further explored, and it remains unclear whether the lizard "tegmentum vasculosum" indeed shares salient similarities with its avian counterpart. There is also no direct evidence that this is the site of endolymph and EP generation in the auditory compartment of the inner ear.

An intriguing report by Ganeshina [1990] identified not just one but three regions of suspected secretory tissue in the crocodilian species Caiman crocodilus: a tegmentum vasculosum very similar to that of birds, Reissner's membrane, and a stria vascularis running along the abneural limbus. All three regions contained both dark and light cells, each of similar cellular morphology between the regions. Therefore, it remains unclear whether these three regions represent truly distinct epithelia. Furthermore, the Caiman stria vascularis showed enough differences to the mammalian stria to conclude that it is an independent development [Ganeshina, 1990].

Evolution of the Inner Ear Endolymphatic System
Mechanisms of Endolymph Production and EP

Generation

The mechanisms of endolymph production and EP generation in the auditory compartments have only been addressed in birds. The involvement of an energy-dependent electrogenic process was confirmed early, by hypoxia experiments [Schmidt and Fernandez, 1962; Necker, 1970]. Under hypoxia, the EP begins to fall rapidly, within $20 \mathrm{~s}$, to negative values around $-20 \mathrm{mV}$. This is reversible upon the restoration of oxygen [Necker, 1970]. A similar decline is observed shortly after death, reaching a stable passive diffusion potential between -12 and $-5 \mathrm{mV}$ [Ninoyu et al., 1987; Schermuly et al., 1990; Sauer et al., 1999] which is less negative than typical values in mammals [Patuzzi, 2011]. Evidence that the electrogenic component is the NKA, present in high density in the dark cells of the tegmentum vasculosum, comes from a variety of in vitro assays, in situ hybridization, and immunohistochemical labeling, summarized in Table 2 [Kuijpers et al., 1967, 1970; Schneider et al., 1987; Yoshihara et al., 1987, 1990; Hossler et al., 2002a; Wilms et al., 2016]. Finally, application of ouabain to perilymph in vivo was shown to reduce the $\mathrm{EP}$, to about $-40 \mathrm{mV}$ within $10 \mathrm{~min}$ [Ninoyu et al., 1987].

Beyond the NKA, other molecular players are only just beginning to be identified. Wilms et al. [2016] probed the avian tegmentum vasculosum for the expression of a whole range of genes known to be important in the mammalian stria vascularis and spiral ligament. In addition to genes coding for four different subunits of NKA, they found expression of relevant components shared with strial marginal cells, e.g., KCNQ1 and KCNE1, encoding the $\mathrm{K}^{+}$-channels KvLQT1 and IsK, and SLC12A2, encoding NKCC1. Importantly, KCNJ10 and KCNJ16, encoding Kir4.1 and Kir5.1 $\mathrm{K}^{+}$-channels, were not found (Table 2).

\section{Mammalian Cochlea}

The mammalian cochlea stands out by maintaining an exceptionally high EP of between +80 and $+120 \mathrm{mV}$ [Schmidt and Fernandez, 1962; Lukashkina et al., 2017; reviewed by Fettiplace, 2017]. The mechanisms of its generation by the stria vascularis are known in more detail than for any other vertebrate group [recent reviews in Nin et al., 2016; Fettiplace, 2017; Wangemann and Marcus, 2017] and will be briefly summarized here.

In mammals, the tissue involved in the generation of the EP resides in the lateral wall [Davis et al., 1958; Tasaki and Spyropoulos, 1959]. The stria vascularis, a specialized multilayered and highly vascularized nonsensory epithelial thickening of the lateral wall, contains the se- 
creting marginal cells as well as the intermediate and basal cells, which build up the gradient for $\mathrm{K}^{+}$and the highly positive EP. Marginal cells constitute the secretory cells facing the endolymph. Neural crest-derived intermediate cells form a discontinuous layer between marginal cells and basal cells and are responsible for the generation of the high EP. Basal cells form a multi-layered epithelial barrier that separates the extracellular spaces of the stria vascularis and the spiral ligament (the outer wall of the cochlea). The latter is mainly built up by five subgroups of fibrocytes. Type I fibrocytes underlie the stria vascularis, type II fibrocytes are situated below the stria vascularis and type I cells, type III fibrocytes line, as a thin layer, the otic capsule, type IV fibrocytes are located lateral to the basilar membrane and anchor it to the lateral wall, and type $\mathrm{V}$ fibrocytes reside above the stria vascularis [Henson and Henson, 1988]. Fibrocytes of subtypes I, II, and $\mathrm{V}$ are highly interconnected, and form a mesenchymal gap-junctional network, which couples nonsensory supporting cells of the organ of Corti with the stria vascularis.

The major pathway for recycling and secretion of cochlear endolymph involves a flow of $\mathrm{K}^{+}$from perilymph to fibrocytes in the spiral ligament and then to basal cells, intermediate cells, and marginal cells, the last of which release $\mathrm{K}^{+}$into the scala media. Each of these steps is precisely orchestrated by a series of gap junctions, channels, pumps, and transporters, many of which have been molecularly identified [Wangemann, 2006].

\section{$\mathrm{K}^{+}$Cycling}

Based on current measurements [Zidanic and Brownell, 1990], some of the $\mathrm{K}^{+}$seems to simply diffuse extracellularly through the perilymph toward the spiral ligament. A possible intracellular pathway would start with the $\mathrm{K}^{+}$uptake by supporting cells. $\mathrm{K}^{+}$released by OHCs is taken up by Deiters cells and then passed via gap junctions to a series of different cell types: first to epithelial cells, from there to outer sulcus cells, and finally to fibrocytes of the spiral ligament [Spicer and Schulte, 1996; Kikuchi et al., 2000]. In mammals, the molecules responsible for $\mathrm{K}^{+}$uptake into Deiters cells are supposed to be KCC3 [Boettger et al., 2003], KCC4 [Boettger et al., 2002], and Kir4.1 [Hibino et al., 1997]. In chicken, however, none of these could be detected by in situ hybridization. In situ hybridization results rather suggest a $\mathrm{K}^{+}$uptake by NKCC1 and NKA [Wilms et al., 2017], as is the case in strial marginal cells and vestibular dark cells [Hibino and Kurachi, 2006; Wangemann, 2006]. $\mathrm{K}^{+}$released by IHCs is thought to diffuse to the spiral limbus, be released into the scala vestibuli, followed by diffusion through the perilymph via the spiral ligament to the stria vascularis [Kikuchi et al., 2000]. Additionally, Marcus and Chiba [1999] detected parasensory $\mathrm{K}^{+}$absorption by outer sulcus cells, which is regulated by purinergic agonists via $\mathrm{P} 2 \mathrm{X} 2$ purinergic receptors [Lee et al., 2001; Kim and Marcus, 2011].

\section{Developmental Origin and Differentiation in \\ Mammals}

The morphological and molecular data reviewed above indicate that some cell types of the vestibular system were inherited by the tegmentum vasculosum and the mammalian lateral wall, including the stria vascularis. However, other cell types, such as intermediate cells or fibrocytes, appear to be mammal specific. To gain further insight into the evolutionary processes will require insight into the genetic pathways underlying the development of the tegmentum vasculosum and the mammalian lateral wall [Peter and Davidson, 2015]. We will therefore summarize our current knowledge of these processes in mammals, as no data are available for other vertebrates. All time points given below relate to the development in the mouse, if not otherwise stated.

\section{Early Development}

The inner ear is mainly made up of epithelial and mesenchymal cells. These two cell types arise from distinct cell lineages during embryonic development. Epithelial cells originate from the otic placode, a specialized region of the surface ectoderm. This area starts to invaginate at embryonic day (E) 8.5 and detaches at E10 to form the otocyst. Subsequent epithelial morphogenesis generates the complex three-dimensional structure of the vestibulum and the coiled cochlea. Cells of the otocyst proliferate, migrate, and differentiate to give rise to the cochleovestibular ganglion and the epithelial sensory and nonsensory cells of the membranous labyrinth [Kiernan et al., 2002; Barald and Kelley, 2004; Chen and Streit, 2013; Patthey et al., 2014]. In contrast, mesenchymal cells are of cranial paraxial origin and start to condense around the otocyst at E10. Cells adjacent to the otic epithelium form the inner mesenchymal compartment and differentiate into otic fibrocytes. In contrast, the outer mesenchymal compartment ossifies to form the bony capsule of the membranous labyrinth.

With respect to the mammalian stria vascularis, marginal cells likely derive from the otic epithelium [Kikuchi and Hilding, 1966; Sher, 1971; Kuijpers et al., 1991; Sagara et al., 1995; Birkenhäger et al., 2001], intermediate cells from neural crest [Cable and Steel, 1991; Tachibana,
18

Brain Behav Evol 2018;92:1-31 DOI: $10.1159 / 000494050$
Köppl/Wilms/Russell/Nothwang 
1999], and basal cells from mesenchymal spiral ligament fibrocytes [Sher, 1971; Ito et al., 1993; Nakazawa et al., 1996; Trowe et al., 2011]. Accordingly, a Tbx18::Cre mouse labels the periotic mesenchyme in lineage tracing studies, a Wnt1::Cre mouse line the neural crest, and a Pax2::Cre mouse line the cochlear duct epithelium [Trowe et al., 2011].

\section{Fibrocyte Differentiation}

Unfortunately, precise information on the genetic factors guiding development of the endolymph-generating cellular apparatus is poor. The transcription factor (TF) gene Pou $3 f 4$ (also known as Brn4), encoding a Pou domain, class $3 \mathrm{TF}$, is confined to cells of mesodermal origin with no expression in epithelial cells [Trowe et al., 2008]. Absence of Pou3f4 function results in deafness both in humans and mice [Kok et al., 1995; Minowa et al., 1999] and concurrent loss of the type IV and type V fibrocyte areas [Song et al., 2011]. Furthermore, ultrastructural analysis revealed markedly fewer cytoplasmic extensions and had few mitochondria in type II fibrocytes [Minowa et al., 1999]. Type I fibrocytes filling the area beneath the stria vascularis also had few mitochondria and the surrounding extracellular matrix was extremely sparse compared with wild-type mice. Accordingly, a reduced EP (approx. $+40 \mathrm{mV}$ compared to approx. $+90 \mathrm{mV}$ in controls) was observed in Pou $3 \mathrm{f4}^{-/-}$mice [Minowa et al., 1999]. No pathological features were detected in other structures of the inner ear. Together, these results suggest that Pou3f4 is a key player in differentiation of the spiral ligament into specific otic fibrocytes.

The T-box TF Tbx18 is another factor present in otic mesenchyme, albeit with a more restricted expression [Trowe et al., 2008]. During embryonic development, its expression is initially confined to the inner zone of the periotic mesenchyme, including the future cochlea and the vestibular portion, and later spreads to prospective fibrocytes of the spiral limbus and the spiral ligament. $T b \times 18^{-/-}$mice show profound deafness, a strongly reduced EP (approx. $+1.3 \mathrm{mV}$ compared to $+103 \mathrm{mV}$ in controls), and lateral wall hypoplasia due to a strong reduction of membranous infoldings of marginal, intermediate, and basal cells, and a marked loss of basal cells [Trowe et al., 2008]. Molecular analysis revealed improper cytodifferentiation of otic fibrocytes with reduced abundance of otospiralin, connexin 26, aquaporin 1, Atp1a1, and Kcc3 and a lack of the breakdown of the basal lamina. Embryonic analysis revealed that loss of $T b x 18$ primarily affects the development of the mesenchymal portion of the cochlea, likely by disturbing boundary for-

Evolution of the Inner Ear Endolymphatic System mation between the otic capsule and otic fibrocytes. It was concluded that the stria vascularis defects resulted from the failure of $T b \times 18^{-/-}$otic fibrocytes to generate the basal cell layer due to an impaired mesenchymal-epithelial transition [Trowe et al., 2008]. Subsequent analysis suggested that canonical Wnt signaling is upstream of Tbx18. $\beta$-Catenin links the canonical Wnt pathway to transcriptional control, and its ablation in the periotic mesenchyme caused strong reduction in Tbx18 expression in the inner (fibrocyte) compartment [Bohnenpoll et al., 2014]. On the cellular level, strongly impaired proliferation and a moderately increased apoptosis in the inner mesenchymal compartment together caused a greatly reduced number of fibrocytes [Bohnenpoll et al., 2014]. Interestingly, the authors noted in the same study that Axin2, a bona fide transcriptional target of canonical Wnt signaling, is only present in the inner mesenchymal compartment and becomes progressively restricted to fibrocytes of the spiral ligament and the stria vascularis. This protein might therefore represent a further promising candidate involved in fibrocyte development.

Another critical factor in the periotic mesenchyme is the HMG-domain containing TF Sox9. During embryonic development, Sox9 expression becomes first restricted to the outer mesenchymal compartment that gives rise to the otic capsule. Subsequently, its expression becomes downregulated in the outer compartment and upregulated in the condensing mesenchymal cells of the developing stria vascularis and the spiral limbus that is derived from the inner periotic mesenchyme [Trowe et al., 2010]. Ablation of Sox9 in the mesenchymal compartment, using a Tbx18::Cre driver line, caused a reduced number of otic fibrocytes in the lateral wall. Furthermore, it impaired differentiation of lateral wall cell subtypes, as connexin 26 and E-cadherin were not present in mesenchymal cells underlying the stria vascularis [Trowe et al., 2010]. As fibrocytes have not been reported in the tegmentum vasculosum, it will be interesting to compare the expression of the above-mentioned genes in birds or frogs.

\section{Intermediate Cells}

Intermediate cells are a type of melanocyte that originate from neuroectodermal tissue, and Sox proteins influence the differentiation of neural crest during its generation [Harris et al., 2010]. In most species, the TFs Sox 9 and Sox10 are expressed in the neural crest [Cheung and Briscoe, 2003; Harris et al., 2010]. Sox9 is a transcriptional activator of Sox 10, which in turn controls transcription of the microphthalmia-associated TF (Mitf). This gene contains multiple promoters, among them the M pro- 
moter, which is selectively used in melanocytes and is targeted by several TFs, including Pax3, Creb, Sox9, Sox10, Lef1, Onecut-2, and Mitf itself [Levy et al., 2006; Passeron et al., 2007]. Mitf in turn controls a set of genes critical for melanogenesis, including Tyrp1, Tyrp2, and Pmel. Interestingly, a spontaneous insertion in the porcine Mitfgene, creating a novel functional silencer, abolished expression of the Mitf $M$ isoform. This genetic variant causes deafness with a Waardenburg syndrome 2 phenotype [Chen et al., 2016], providing compelling evidence how alterations in cis-regulatory elements are able to generate dramatic phenotypic alterations.

Another critical factor in the development of the neural crest is Pax3, as it is involved in regulating the transition from early melanoblasts derived from the neural crest to mature melanocytes, and in their survival [Cheung and Briscoe, 2003; Kim et al., 2014]. Of note, ablation of Pax3 in mice also affected the dark cell region of cristae and maculae [Kim et al., 2014]. As these mice die at birth, a detailed analysis of the affected cell type requires refined genetic ablation of Pax3.

\section{Marginal Cells}

Developmental pathways involved in the generation of these secretory cells in the stria vascularis are poorly known. In the mouse inner ear, expression of the nuclear receptor family member estrogen-related receptor- $\beta$ (Esrrb, also known as Nr3b2) was observed in the vestibular dark cells of the crista ampullaris and utricle, and in the marginal cells of the stria vascularis. Mice with a Sox2::Cre targeted loss of Esrrb revealed auditory and vestibular defects such as head bobbing, circling behavior, and a threshold in excess of $100 \mathrm{~dB}$ SPL for auditory brainstem responses [Chen and Nathans, 2007]. Morphological alterations included narrowing of the membranous labyrinths of the three semicircular canals, flattening of the ampullae, and reduction of the scala media. On the molecular level, multiple channels and transporter transcripts, such as Kcnq1, Kcne1, Atp1b2, Atpla1, and Slc12a2, showed reduced expression in marginal cells (dark cells were not analyzed).

\section{Toward Mechanisms of Endolymph and EP Evolution: Cell Types, Their Roles and Molecular Repertoires}

This section focusses on the mechanisms of evolution of endolymph and EP. We identify important questions regarding the phylogeny of the cell types responsible for endolymph production and EP generation that open future avenues for investigation.

\section{Are Dark Cells the Common Element?}

The many shared properties of dark cells and strial marginal cells, and their crucial role as the final $\mathrm{K}^{+}$secretion step into endolymph, have often been pointed out [Wangemann, 1995; Hibino and Kurachi, 2006]. This has led to the common assumption that dark cells are a plesiomorphic element, with a common evolutionary origin across all tissues involved in endolymph secretion. Conclusive evidence to support this notion is lacking. The above review has identified important gaps that are worthy of further exploration.

For example, no equivalents of dark cells have been identified in the lateral line, despite clear evidence for maintenance of a high $\left(\mathrm{K}^{+}\right)$microenvironment around the hair cells that involves electrogenic pumping (see the section: The Site of Electrogenic Pumping of Potassium in Lateral Line Organs). Similarly, in teleost fish, the closest equivalent to dark cells are typical ionocytes of the inner ear (see Dark Cells; Fig. 6), but the evolutionary relationship of dark cells to ionocytes (i.e., whether they are homologous) is not clear. Ionocytes, also called chloride cells or mitochondria-rich cells, have been most thoroughly characterized in the gills of freshwater teleosts. There, several subtypes are known that differ in morphology and in their molecular repertoire of channels, cotransporters, and pumps, with substantial variability between fish species [recent reviews in Dymowska et al., 2012; Hwang and Chou, 2013; Guh et al., 2015]. None of these subtypes of gill ionocytes appears to be a direct equivalent of inner ear dark cells. However, the variety of ionocytes in freshwater teleosts suggests an apomorphic (derived) condition. It has been argued that the uniform ionocyte type of the gills of saltwater fish represents the plesiomorphic condition for teleosts and that it is characterized by expressing NKA, NKCC1, CFTR and an inwardly rectifying $\mathrm{K}^{+}$channel [Hwang et al., 2011; Takei et al., 2014]. This is largely similar to dark cells (except CFTR, cystic fibrosis transmembrane regulator $\mathrm{Cl}^{-}$channel). Inner ear ionocytes of teleosts have not been tested for expression of any of those genes or proteins and this might be an obvious starting point in search of a common ancestor of ionocytes and dark cells.

Related to that, our review showed that there is substantial variability in the candidate secretory tissues across endorgans and across the vertebrate groups. There are multiple potential sites of endolymph secretion (see the section: Vestibular Tissues Associated with Endo- 
lymph Production and Maintenance) and their relative roles remain to be clarified. Not all of those potential sites even contain dark cells (e.g., the planum semilunatum, the sacculus, or the semicircular canal ducts). Other sites show peculiar differences in the cellular layout; compare, for example, the crista-flanking zones in birds (with alternating dark and light cells) and mammals (where these cell types form adjacent but separate populations; Fig. 4, 5).

It is currently unclear whether these differences in the mature conditions represent profoundly different, independent evolutionary innovations or subsequent modifications of a shared plesiomorphic condition. Modern approaches to the developmental mechanisms of evolution, comparing different vertebrate groups, could help shed light on these questions.

\section{Beyond Dark Cells: How Many (Shared) Types?}

Another point that has received comparatively little attention is that dark cells are probably never the sole element involved in endolymph secretion and EP generation. Although this is well appreciated for the mammalian stria vascularis, its layered structure and several crucial cell types are commonly contrasted just to the vestibular dark cell. Yet both in the vestibular system and in the tegmentum vasculosum of nonmammalian auditory inner ear compartments, there is always at least one other type of cell believed to be involved in endolymph homeostasis. Those cells have been assigned various names and it is unclear at this point how much of the variety in terminology has simply historically grown (with different investigators being unaware of each other's work), as opposed to reflecting true differences. We suggest these cells can be tentatively grouped into at least two types that we call transitional cells and light cells (see the section: Cell Types and Mechanisms of Endolymph Production and EP Generation; Fig. 6). A consistent feature of both cell types appears to be that they are extensively coupled to each other - but not to dark cells - by gap junctions. However, very little is known about their molecular repertoire and physiological role. Two salient questions thus emerge, as discussed below.

Is There a Common, Ancestral Cell Type of

Endolymph-Producing Tissues?

Several authors perceived a morphological continuum between the supporting cells of the sensory epithelia and either light cells [ten Cate and Rarey, 1992; Helling and Merker, 2005] or transitional cells [Kikuchi et al., 1994]. Furthermore, we have, again by morphological criteria, tentatively grouped the pale ionocytes of the teleost inner ear among the transitional cell type, suggesting a potential continuum even with ionocytes and dark cells. Whether these similarities indicate a common descent, possibly shared by all epithelial ion-transporting cell types of the inner ear, can only be clarified by an evo-devo approach.

One tantalizing piece of evidence along those lines is that, during a phase of mammalian development, transitional cells very likely assume the classic dark cell function of $\mathrm{K}^{+}$secretion, because they express NKCC1 at postnatal stages when dark cells do not yet do so [Bartolami et al., 2011]. In the mature condition, NKCC1 is expressed by both cell types, and transitional cells are then suggested to switch to a modulatory role, with the primary task of absorbing $\mathrm{K}^{+}$from endolymph [Bartolami et al., 2011].

Transitional Cells and Light Cells: Two

Plesiomorphic, Functionally Different Cell Types

or Convergent Evolution of Two Functionally

Analogous Cell Types?

The distinction between transitional cells and light cells traditionally separates the mammalian from the nonmammalian literature. We summarized tentative evidence that these really are two different cell types on morphological criteria (see the section: Cell Types and Mechanisms of Endolymph Production and EP Generation). However, this still leaves two possible interpretations regarding their evolution. Transitional cells and light cells might share a common origin and have become specialized for two different functions in inner ear fluid homeostasis. An alternative interpretation is that transitional cells and light cells represent convergently (independently) evolved solutions for a shared, but so far poorly identified, function in endolymph secretion and EP generation.

Currently, there is no real evidence for either interpretation and, again, modern evo-devo approaches such as marker profiling should be illuminating here. Our suggestions to: (a) regard cells of the planum semilunatum and "associate cells" of the teleost inner ear as light cell types, and (b) group pale ionocytes of the teleost inner ear among transitional cells, are more in line with the first interpretation (i.e., several plesiomorphic functions). A further open question is the relationship of these cells to the basal cells of the mammalian stria vascularis (Fig. 6).

\section{The Only Clear Case: Melanocytes}

The only reasonably clear case of cell type phylogeny in the context of endolymph-associated tissues is that of 
neural crest-derived melanocytes. Interestingly, this appears to be a cell type that is, in the plesiomorphic condition, not directly involved in endolymph secretion and EP generation (see Melanocytes in the Vestibular System). It is newly recruited into the mammalian stria vascularis as intermediate cells, with a crucial role in EP generation (see Mammalian Cochlea). An interesting issue is whether melanocytes in the inner ear have a protective function, and whether this persists across vertebrates.

\section{Evolution of Endolymph and EP: Functional Selective Pressures}

In this section, we aim to identify the selective pressures that led to the evolution of the specific composition of endolymph and the magnitude of the EP. In other words, why did these features evolve and why did they evolve differently in different vertebrate groups or inner ear compartments? Hypotheses about selective pressures provide the necessary background to guide the choice of model species for specific research questions.

\section{The Role of High $\left(\mathrm{K}^{+}\right)$}

The predominant selective advantage of a high $\left(\mathrm{K}^{+}\right)$in endolymph is generally believed to be an energy-saving effect for the hair cells, as first suggested by Davis [1965]. The hair cells of the inner ear are positioned right at the interface between the endolymph and perilymph, their apical hair bundles being exposed to endolymph while their cell bodies face a perilymph-like environment. As a consequence, the predominant ion entering through the mechanoelectrical transduction channels is $\mathrm{K}^{+}$, which will leave again passively upon opening of the hair cell's basolateral $\mathrm{K}^{+}$channels. Basically, most of the metabolically demanding ion pumping has thus been outsourced to the specialized endolymph-producing tissues of the inner ear, enabling the sensory hair cells to operate with minimal energy requirement and minimizing the mechanical noise introduced by blood capillaries. It is important to remember that this advantage already applies without a highly positive EP, as long as some electrical gradient is maintained between endolymph and hair cells to drive transduction. The advantage of high $\left(\mathrm{K}^{+}\right)$is further enhanced when $\left(\mathrm{Na}^{+}\right)$is concomitantly lowered, as is the case in the inner ear of all land vertebrates (Fig. 3b). This is because the hair cells' mechanoelectrical transduction channels are nearly equally permeable for $\mathrm{Na}^{+}$and $\mathrm{K}^{+}$[Fettiplace and Kim, 2014]. The relative proportions of $\mathrm{Na}^{+}$and $\mathrm{K}^{+}$influx during transduction are thus deter- mined by their respective electrochemical gradients across the apical cell membrane. Lower $\left(\mathrm{Na}^{+}\right)$means less $\mathrm{Na}^{+}$influx, which has to be actively pumped out from hair cells, and more $\mathrm{K}^{+}$influx which passively leaves hair cells. In the fish inner ear, where $\left(\mathrm{Na}^{+}\right)$is nearly as high as $\left(\mathrm{K}^{+}\right)$, $\mathrm{Na}^{+}$should be carrying a much more substantial part of the transduction current than in land vertebrates, and the metabolic advantage will be smaller.

The high $\left(\mathrm{K}^{+}\right)$found in endolymph has also been suggested to play a role in maintaining physical stability [Trincker, 1962], because in many animals the labyrinthine endolymph is made viscous by the presence of $\mathrm{K}^{+}$ salts of acid mucopolysaccharides [Vilstrup and Jensen, 1961]. It is therefore interesting that the open canal fluid in dogfish, which contains little $\mathrm{K}^{+}$, is not notably gelatinous, whereas the endolymph of the mainly closed, large, lateral line canals in the teleost Lota, which is rich in $\mathrm{K}^{+}$, is very viscous [Hyrtl, 1866] (I.J.R., pers. observation). It is possible that the increased $\left(\mathrm{K}^{+}\right)$of the canal lymph of these organs has more to do with maintaining the viscosity of the fluid [Vilstrup and Jensen, 1961; Trincker, 1962]. In other words, the functional significance of increased $\left(\mathrm{K}^{+}\right)$in the "endolymph" of these closed lateral line systems probably has to do with impedance matching (i.e., with optimizing the coupling of nanoscale water displacements to the displacements of the sensory hairs bathed in a gelatinous cupula). A microsystem that mimics the endolymph and the EP of the cochlea is housed within the cupula itself, at least for the Xenopus lateral line system. Observations and measurements from the tectorial membrane of the mammalian cochlea [KronesterFrei, 1979; Steel, 1983; Ghaffari et al., 2013] showed that the ionic microenvironment can significantly change its size and physical properties. Low $\left(\mathrm{Ca}^{2+}\right)$ and high $\left(\mathrm{K}^{+}\right)$in the cupula may therefore have very important implications for its structure and physical properties, and the way it couples external forces to the sensory hair cells.

\section{Role of the EP}

The magnitude of the positive EP maintained in endolymph relative to perilymph varies to a significant degree between different inner ear compartments and also between different vertebrate species. While vestibular compartments rather uniformly maintain an EP at around +5 $\mathrm{mV}$, the auditory compartments of birds and, most strikingly, mammals show a clear increase above that (Fig. 3c; Table 1). It is generally agreed that any positive extracellular potential around the hair cell bundles augments the electrical gradient, i.e., the major driving force for the influx of $\mathrm{K}^{+}$and $\mathrm{Ca}^{2+}$ during transduction. However, there 
are some caveats about assuming that the EP as commonly measured in the large endolymphatic spaces is identical to the microenvironment immediately surrounding the hair bundles. We will briefly discuss these before turning to the question of what may have favored the evolution of an increased EP.

Microenvironments around the Hair Cell Bundles

As highlighted in the earlier section on lateral line, despite the lack of a true endolymphatic space, there exists a specialized microenvironment of significantly elevated $\left(\mathrm{K}^{+}\right)$and a substantial positive ECP of up to +55 $\mathrm{mV}$ in the immediate vicinity of the hair cell bundles where sensory transduction takes place. Some intriguing isolated findings suggest that the same may be true even in vestibular and auditory endorgans that maintain large enclosed endolymphatic spaces. There are two independent reports that are at odds with most other vestibular EP measurements (Table 1). Both Trincker [1957] and Dayal [1970] reported values around $+30 \mathrm{mV}$ in the vestibular ampullae, and as high as $+70 \mathrm{mV}$ at the surface of and inside the cupula. In the mammalian cochlea, electrode penetrations under visual control have shown perilymph-like conditions in the inner sulcus space, with zero potential [Manley and Kronester-Frei, 1980] and low $\left(\mathrm{K}^{+}\right)$[Runhaar and Manley, 1987]. Together with morphological evidence for possible barriers formed by the tectorial membrane [Kronester-Frei, 1979] or other extracellular material [Santi and Anderson, 1987], this suggests the existence of a specialized microenvironment in the subtectorial space immediately around the haircell bundles.

The existence of such microenvironments does not necessarily imply that the conditions therein differ in every case from the endolymphatic spaces at large. However, the example of the lateral line most clearly demonstrates that they can. It should prove insightful to clarify how the cupular microenvironment in the lateral line is generated and whether those mechanisms share plesiomorphic features with the vestibular inner ear.

\section{An Increased EP Does Not Convey Superior \\ Sensitivity}

As pointed out above, the auditory compartments of birds and, most strikingly, mammals show a clear increase in the positive EP maintained in endolymph versus perilymph. It is well known that a compromised EP causes a loss in auditory sensitivity, leading to the common conclusion that the high cochlear EP serves to increase the sensitivity of hearing [Hibino et al., 2010]. However, this



Fig. 9. Group average audiograms. Data points were obtained behaviorally [replotted using the values provided by Fay, 1988, p. 557]. Each audiogram shows hearing threshold as a function of frequency. The legend also lists median EP values for each group (see Table 1), to emphasize the correlation with the upper frequency limits of hearing.

does not hold true across vertebrate groups. The best hearing thresholds of mammals are not consistently lower than those of other vertebrates [Fay, 1988; Manley et al., 2018]. Indeed, Figure 9 strikingly illustrates that it is not sensitivity per se but rather sensitivity to higher frequencies that sets birds, and especially mammals, apart. There are isolated exceptions, for example ultrasonic hearing in some frog species [Feng et al., 2006; Arch et al., 2012] or the low hearing limits of humans and elephants [Heffner and Heffner, 1982; ISO, 2003]. However, as a rule, birds are sensitive to high frequencies of $7-8 \mathrm{kHz}$, mammals to $50-80 \mathrm{kHz}$, while fish, amphibians, and nonavian reptiles remain restricted to an upper limit of 1-4 $\mathrm{kHz}$. This correlates with a modest (in birds) and a very large (in mammals) increase in EP (Fig. 3c, 9). Furthermore, within birds, the barn owl shows an unusually high EP of $+34 \mathrm{mV}$ [Wilms et al., 2016], correlated with extended high-frequency sensitivity up to $12 \mathrm{kHz}$ [Dyson et al., 1998], and within a typical mammalian cochlea, there is a modest increase of EP along the tonotopic gradient towards the high-frequency base [Salt et al., 1989]. Thus, it appears that selection for an increase in the EP was not 
driven by a general gain in sensitivity or increased drive for hair-cell transduction, but more specifically by improving hair-cell performance at high auditory frequencies [Wilms et al., 2016].

Maintaining Oscillatory Voltage Responses to Drive Electromotility at High Frequencies

For all hair cells, voltage differences between the inside and the outside of the cells develop due to the flow of the receptor current in through the mechanoelectrical transduction channels at the tips of the stereocilia and out across the electrical resistance of the plasma membrane. These voltage differences control transmitter release for any hair cell with afferent synaptic terminals. Voltage differences cause depolarization of the presynaptic membranes of the afferent synapses, gate $\mathrm{Ca}^{2+}$ entry via L-type voltage-dependent $\mathrm{Ca}^{2+}$ channels, which triggers the exocytosis of neurotransmitter and initiation of postsynaptic signaling to the central nervous system.

For mammalian OHCs, the voltage difference between the intracellular and extracellular potentials, generated by the transduction current, also drives their unique prestindriven, voltage-dependent somatic motility: the cylindrically shaped OHCs contract and stiffen at depolarized intracellular potentials and extend and relax when the intracellular potential hyperpolarizes [reviewed by Ashmore, 2008]. OHCs have been suggested to act as a "cochlear amplifier," delivering critically timed injections of energy during the period of maximum velocity in each cycle of mechanical displacement in response to a sound stimulus [Nilsen and Russell, 1999]. However, electromotility faces a problem at high frequencies: the membrane capacitance, by being in parallel with the membrane resistance, acts as a low pass filter, which should attenuate the amplitude of periodic voltage signals (AC component) above a few hundred hertz, as has been shown for most hair cells, including mammalian IHCs [Crawford and Fettiplace, 1980; Holton and Weiss, 1983; Russell and Sellick, 1983; Palmer and Russell, 1986]. When low-pass filtered by the hair cell's membrane capacitance, the phasic AC component of the receptor potential is attenuated and smoothed to produce a DC potential, but only for hair cells (i.e., IHCs), which generate asymmetrical receptor potentials [Palmer and Russell., 1986; reviewed by Fettiplace, 2017]. It is this DC component that controls the release of the afferent synaptic transmitter in response to tones at high frequencies, above approximately $2 \mathrm{kHz}$.

Cochlear amplification by $\mathrm{OHC}$, however, must operate at ultrasonic frequencies to cope with the hearing ranges of many mammalian species, notably bats and cetaceans. In vitro, limited only by the frequency response of the measurement system, voltage-dependent motility has been demonstrated to extend to $70 \mathrm{kHz}$ in isolated OHC [Frank et al., 1999]. Two mechanisms that depend on a high EP are suggested to enable mammals to hear high frequency sounds. One serves to maximize the intracellular voltage change, the other adds extracellular voltage (as detailed in the following paragraphs). Together, they maximize the oscillatory voltage difference across the hair cell's membrane that drives electromotility.

Pushing the Limit of Intracellular Voltage Oscillations. Mammalian OHCs show several salient specializations that, together with the enhanced electrical gradient from a high EP, enable them to generate significant AC membrane potential changes at frequencies at least as high as $10 \mathrm{kHz}$ [Fettiplace, 2017]. Firstly, due to the low $\left(\mathrm{Ca}^{2+}\right)$ in the endolymph [Bosher and Warren, 1968] and very high concentrations of intracellular calcium buffer, the mechanoelectrical transduction channels of OHCs are kept at an increased open probability of about 0.5 at rest [Johnson et al., 2011]. This means that, at any point in time, even in complete silence, half of these channels are open in $\mathrm{OHC}$, in contrast to only about 5\% in IHCs [Fettiplace, 2017]. Consequently, upon stimulation, the receptor current modulates nearly symmetrically around the resting state in $\mathrm{OHC}$, generating more sinusoidal receptor potentials than in other hair cells, which maximizes cochlear sensitivity to very quiet sounds [Russell et al., 1986]. Secondly, not only the transduction channels but also the basolateral KCNQ4 channels have an unusually high resting open probability which together leads to a large "silent current" flowing through OHC at rest. Importantly, this silent current is primarily driven by the electrical gradient for $\left(\mathrm{K}^{+}\right)$which is determined by the "batteries" of the EP and $\mathrm{OHC}$ resting potential in series (Fig. 10). In addition, the conductance of both types of channels increases with increasing frequency along the tonotopic axis of the cochlea [Johnson et al., 2011]. Thus, the total conductance of OHCs and the "silent current" increase systematically with frequency position. Thirdly, OHC size decreases tonotopically towards higher frequencies in many, but not in all mammalian species, thereby reducing the total membrane capacitance. All the above characteristics, including a high EP, work together to reduce the membrane time constant and extend the upper limit for sinusoidal modulation of the membrane potential to frequencies $>10 \mathrm{kHz}$ [Fettiplace, 2017]. This is vital for driving voltage-dependent somatic motility at high frequencies but may still not be sufficient to extend into the ultrasonic range. 
Fig. 10. A schematic cross-section of the mammalian cochlea based on the Davis [1957] model for converting receptor current to receptor potential. Receptor current $\left(\mathrm{I}_{(\mathrm{H}) \mathrm{t}}\right)$ is driven through the variable conductance of the apically located mechanoelectrical transduction channels $\left(\mathrm{R}_{\mathrm{a}}\right)$ located on the tips of the stereocilia of the IHCs and $\mathrm{OHCs}$ by two batteries in series: EP $(+80 \mathrm{mV})$ and cell resting potential, -45 (IHC) or $-54 \mathrm{mV}$ (OHC). The transduction channels are gated when the stereocilia are displaced (pale grey arrows). An intracellular receptor potential $\left(\mathrm{V}_{(\mathrm{H}) \mathrm{t}}=\mathrm{I}_{(\mathrm{H}) \mathrm{t}} \times\right.$ $\mathrm{R}_{\mathrm{b}}$ ) is generated by the flow of $\mathrm{I}_{(\mathrm{H}) \mathrm{t}}$ across the resistance $\left(\mathrm{R}_{\mathrm{b}}\right)$ of the IHC and OHC basolateral cell membranes. $\mathrm{V}_{(\mathrm{H}) \mathrm{t}}$ is electrically low-pass filtered by the hair cell membrane capacitance $\left(\mathrm{C}_{\mathrm{a}}\right.$ and $\left.\mathrm{C}_{\mathrm{b}}\right)$. An extracellular receptor potential $\left(\mathrm{V}_{(\mathrm{OC}) \mathrm{t}}\right)$ is generated in the organ of Corti in the close vicinity of the OHCs by the return flow of receptor current $\mathrm{I}_{(\mathrm{OC}) t}$ across the resistance of the organ of Corti ( $\left.\mathrm{R}_{\mathrm{OC}}\right)$. $\mathrm{V}_{(\mathrm{OC}) \mathrm{t}}$ is not subject to electrical low-pass filtering by the hair cell membrane capacitance.

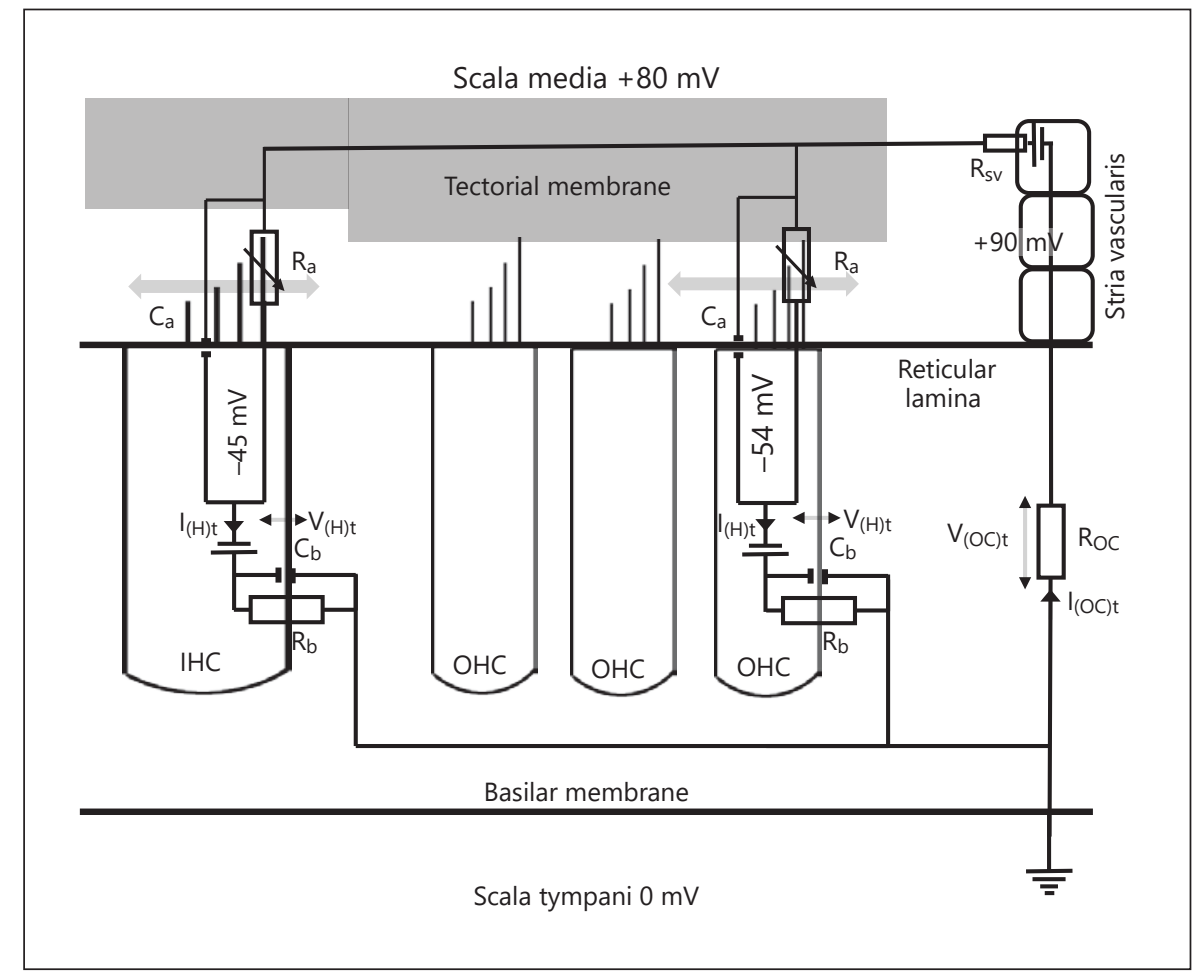

Roles for Extracellular Potentials in Cochlear Amplification? An intriguing suggestion first put forward by Dallos and Evans [1995], is that electromotility at ultrasonic frequencies might predominantly be driven by extracellular potentials within the organ of Corti that arise due to the return flow of receptor current across the resistance of the cochlea partition (Fig. 10). Intracellular potentials, but not the extracellular potentials, would be subject to low-pass filtering by the $\mathrm{OHC}$ membrane capacitance. These extracellular potentials depend on the flow of receptor current, which in turn depends on the EP. Recent experiments on mutant mice provide fresh support for this notion. Measurements were obtained from a mouse strain (CD-1) with a mutation (A88V) for connexin 30 (Cx30), which targets gap junctions between supporting cells in the organ of Corti and stria vascularis in the cochlea [Bosen et al., 2014]. Mice expressing the mutation (CD-1 Cx30A88V) have an unusually low $+70 \mathrm{mV} \mathrm{EP}$ compared with $+112 \mathrm{mV}$ in the wild-type CD-1 mouse. As expected, they have impaired hearing for frequencies below $12 \mathrm{kHz}$ compared with that of wild-type mice. Presumably, following the discussion above, this is because of a reduced flow in receptor current, and hence reduced OHC receptor potentials due to the reduced EP. Surprisingly, the CD-1 Cx30A88V mice have more sensitive

Evolution of the Inner Ear Endolymphatic System hearing than wild-type CD-1 mice at frequencies above $20 \mathrm{kHz}$, despite their reduced EP [Lukashkina et al., 2017]. This high sensitivity of high-frequency hearing in CD-1 $\mathrm{Cx} 30 \mathrm{~A} 88 \mathrm{~V}$ mice is unexpected if $\mathrm{OHC}$ electromotility is driven by intracellular receptor potentials, which would be reduced by a decrease in EP. However, it might be explained if the voltage for $\mathrm{OHC}$ electromotility is determined largely by extracellular receptor potentials generated by the flow of a reduced receptor current across a cochlear partition with a concomitant increase in resistance. The Cx30A88V mutation increases the resistance (and hence decreases the flow of ions and small molecules) across gap junctions [Essenfelder et al., 2004]. Increase in cochlear partition resistance is intended to preserve the amplitude of the receptor potential despite a decrease in extracellular receptor current (Fig. 10).This proposal is supported by the finding that the amplitudes of the peak extracellular receptor potentials of CD-1 CX$30 \mathrm{~A} 88 \mathrm{~V}$ mice are closely similar to those measured from another mouse strain that normally has similar excellent high frequency hearing sensitivity [Lukashkina et al., 2017]. Based on these measurements, it is tentatively suggested that for frequencies below $12 \mathrm{kHz}, \mathrm{OHC}$ electromotility is primarily driven by the $\mathrm{OHC}$ receptor potential. For frequencies above approximately $12 \mathrm{kHz}$, the 
transmembrane control voltage for $\mathrm{OHC}$ electromotility is dominated by extracellular potentials that are not filtered by the membrane capacitance of the OHCs. Under normal circumstances, a high EP is an essential requirement for this proposed mechanism.

\section{Maintaining Oscillatory Voltage Responses to Drive}

Neural Phase Locking at High Frequencies?

The principal problem of maintaining a significant AC voltage drive at high frequencies applies equally to neural phase locking. In the guinea pig, low-pass filtering of the IHC membrane was shown to be the likely limiting factor for phase-locked voltage-dependent transmitter release at the afferent synapse and phase-locked spiking of the auditory nerve [Palmer and Russell, 1986]. Guinea pig auditory-nerve fibers have an upper limit of phase locking at about $3.5 \mathrm{kHz}$, similar to most other mammals and birds [Köppl, 1997]. Auditory nerve fibers in the barn owl show phase locking up to exceptional frequencies of near $10 \mathrm{kHz}$ [Köppl, 1997], but the mechanisms enabling this remain unexplained. Intriguingly, the barn owl also maintains a higher EP than other birds (Table 1). We thus suggest that similar selective pressures have acted on the EP of the barn owl and of mammals, the functional gain in both cases being a significant AC driving voltage at higher frequencies, for neural phase locking (owl) or $\mathrm{OHC}$ electromotility (mammals).

\section{Statement of Ethics}

The authors have no ethical conflicts to disclose.

\section{Disclosure Statement}

The authors have no conflicts of interest to declare.

\section{Funding Sources}

The authors gratefully acknowledge continuous funding over many years by the Deutsche Forschungsgemeinschaft for their work. I.J.R. is funded by the Medical Research Council MR/ N004299/1.

\section{References}

Arch VS, Simmons DD, Quinones PM, Feng AS, Jiang J, Stuart BL, Shen JX, Blair C, Nargeot J (2012): Inner ear morphological correlates of ultrasonic hearing in frogs. Hear Res 283:7079.

Art JJ, Fettiplace R (1984): Efferent desensitization of auditory nerve fibre responses in the cochlea of the turtle Pseudemys scripta elegans. J Physiol 356:507-523.

Ashmore J (2008): Cochlear outer hair cell motility. Physiol Rev 88:173-210.

Baker GE, de Grip WJ, Turton M, Wagner HJ, Foster RG, Douglas RH (2015): Light sensitivity in a vertebrate mechanoreceptor? J Exp Biol 218:2826-2829.

Barald KF, Kelley MW (2004): From placode to polarization: new tunes in inner ear development. Development 131:4119-4130.

Bartolami S, Gaboyard S, Quentin J, Travo C, Cavalier M, Barhanin J, Chabbert C (2011): Critical roles of transitional cells and $\mathrm{Na} / \mathrm{K}$ ATPase in the formation of vestibular endolymph. J Neurosci 31:16541-16549.

Becerra M, Anadon R (1993): Fine structure and development of ionocyte areas in the labyrinth of the trout (Salmo trutta fario). J Anat 183:463-474.

Bernard C, Ferrary E, Sterkers O (1986): Production of endolymph in the semicircular canal of the frog Rana esculenta. J Physiol 371:1728.
Birkenhäger R, Otto E, Schurmann MJ, Vollmer M, Ruf EM, Maier-Lutz I, Beekmann F, Fekete A, Omran H, Feldmann D, Milford DV, Jeck N, Konrad M, Landau D, Knoers NV, Antignac C, Sudbrak R, Kispert A, Hildebrandt F (2001): Mutation of BSND causes Bartter syndrome with sensorineural deafness and kidney failure. Nat Genet 29:310-314.

Boettger T, Hubner CA, Maier H, Rust MB, Beck FX, Jentsch TJ (2002): Deafness and renal tubular acidosis in mice lacking the $\mathrm{K}-\mathrm{Cl}$ cotransporter Kcc4. Nature 416:874-878.

Boettger T, Rust MB, Maier H, Seidenbecher T, Schweizer M, Keating DJ, Faulhaber J, Ehmke H, Pfeffer C, Scheel O, Lemcke B, Horst J, Leuwer R, Pape HC, Volkl H, Hubner CA, Jentsch TJ (2003): Loss of K-Cl co-transporter KCC3 causes deafness, neurodegeneration and reduced seizure threshold. EMBO J 22: 5422-5434.

Bohnenpoll T, Trowe M-O, Wojahn I, Taketo MM, Petry M, Kispert A (2014): Canonical Wnt signaling regulates the proliferative expansion and differentiation of fibrocytes in the murine inner ear. Dev Biol 391:54-65.

Bosen F, Schutz M, Beinhauer A, Strenzke N, Franz T, Willecke K (2014): The Clouston syndrome mutation connexin $30 \mathrm{~A} 88 \mathrm{~V}$ leads to hyperproliferation of sebaceous glands and hearing impairments in mice. FEBS Lett 588: 1795-1801.
Bosher SK, Warren RL (1978): Very low calcium content of cochlear endolymph, an extracellular fluid. Nature 273:377-378.

Brusatte SL, O'Connor JK, Jarvis ED (2015): The origin and diversification of birds. Curr Biol 25:R888-R898.

Burnham JA, Stirling CE (1984a): Quantitative localization of $\mathrm{Na}-\mathrm{K}$ pump site in frog inner ear dark cells. Hear Res 13:261-268.

Burnham JA, Stirling CE (1984b): Quantitative localization of $\mathrm{Na}-\mathrm{K}$ sites in the frog sacculus. J Neurocytol 13:617-638.

Cable J, Steel KP (1991): Identification of two types of melanocyte within the stria vascularis of the mouse inner ear. Pigment Cell Res 4: 87-101.

Cahn PH, Shaw E (1962): The first demonstration of lateral line cupulae in the Mugiliformes. Copeia 1962:109.

Carr CE, Soares D (2002): Evolutionary convergence and shared computational principles in the auditory system. Brain Behav Evol 59: 294-311.

Chen J, Nathans J (2007): Estrogen-related receptor beta/NR3B2 controls epithelial cell fate and endolymph production by the stria vascularis. Dev Cell 13:325-337.

Chen J, Streit A (2013): Induction of the inner ear: stepwise specification of otic fate from multipotent progenitors. Hear Res 297:3-12. 
Chen L, Guo W, Ren L, Yang M, Zhao Y, Guo Z, Yi H, Li M, Hu Y, Long X, Sun B, Li J, Zhai S, Zhang T, Tian S, Meng Q, Yu N, Zhu D, Tang G, Tang Q, Ren L, Liu K, Zhang S, Che T, Yu $\mathrm{Z}$, Wu N, Jing L, Zhang R, Cong T, Chen S, Zhao Y, Zhang Y, Bai X, Guo Y, Zhao L, Zhang F, Zhao H, Zhang L, Hou Z, Zhao J, Li J, Zhang L, Sun W, Zou X, Wang T, Ge L, Liu Z, Hu X, Wang J, Yang S, Li N (2016): A de novo silencer causes elimination of MITF-M expression and profound hearing loss in pigs. BMC Biol 14:52.

Cheung M, Briscoe J (2003): Neural crest development is regulated by the transcription factor Sox9. Development 130:5681-5693.

Citron L, Exley D, Hallpike CS (1956): Formation, circulation and chemical properties of the labyrinthine fluids. Br Med Bull 12:101-104.

Ciuman RR (2009): Stria vascularis and vestibular dark cells: characterisation of main structures responsible for inner-ear homeostasis, and their pathophysiological relations. J Laryngol Otol 123:151-162.

Clack JA (1997): The evolution of tetrapod ears and the fossil record. Brain Behav Evol 50: $198-212$.

Clason E (1873): Die Morphologie des Gehörorgans der Eidechsen. Anat Studien 1:300-376.

Corey DP, Hudspeth AJ (1983): Kinetics of the receptor current in bullfrog saccular hair cells. J. Neurosci 3:962-976.

Cotanche DA, Cotton CU, Gatzy JT, Sulik KK (1987): Ultrastructural and electrophysiological maturation of the chick tegmentum vasculosum. Hear Res 25:125-139.

Cotanche DA, Sulik KK (1982): Scanning electron microscopy of the developing chick tegmentum vasculosum. Scan Elect Microsc 3:12831294.

Crawford AC, Evans MG, Fettiplace R (1991): The actions of calcium on the mechano-electrical transducer current of turtle hair cells. J Physiol 434:369-398.

Crawford AC, Fettiplace R (1980): The frequency selectivity of auditory nerve fibres and hair cells in the cochlea of the turtle. J Physiol 306: 79-125.

Dallos P, Evans BN (1995): High-frequency motility of outer hair cells and the cochlear amplifier. Science 267:2006-2009.

Davis H (1957): Biophysics and physiology of the inner ear. Physiol Rev 37:1-49.

Davis H (1961): Some principles of sensory receptor action. Physiol Rev 41:391-416.

Davis H (1965): A model for transducer action in the cochlea. Cold Spring Harb Symp Quant Biol 30:181-190.

Davis H, Deatherage BH, Rosenblut B, Fernandez C, Kimura R, Smith CA (1958): Modification of cochlear potentials produced by streptomycin poisoning and by extensive venous obstruction. Laryngoscope 68:596-627.

Dayal VS (1970): D.C. potentials in the semi-circular canal of the pigeon. Acta Otolaryngol 69:254-256.
Deiters O (1860): Untersuchungen über die Schnecke der Vögel. Arch Anat Physiol Wiss Med 1860:409-460.

Deiters O (1862): Ueber das innere Gehörorgan der Amphibien. Arch Anat Physiol Wiss Med 1862:262-275, 277-310.

Dinklo T (2005): Mechano- and electrophysiological studies on cochlear hair cells and lateral line cupulae; $\mathrm{PhD}$ thesis, University of Groningen, Groningen.

Dohlman GF (1964): Secretion and absorption of endolymph. Trans Am Otol Soc 52:96-113.

Dohlman GF (1965): The mechanism of secretion and absorption of endolymph in the vestibular apparatus. Acta Otolaryngol 59:275-288.

Dymowska AK, Hwang PP, Goss GG (2012): Structure and function of ionocytes in the freshwater fish gill. Respir Physiol Neurobiol 184:282-292.

Dyson ML, Klump GM, Gauger B (1998): Absolute hearing thresholds and critical masking ratios in the European barn owl: a comparison with other owls. J Comp Physiol A 182: 695-702.

Enger PS (1964): Ionic composition of the cranial and labyrinthine fluids and saccular D.C. potentials in fish. Comp Biochem Physiol 11: 131-137.

Essenfelder GM, Bruzzone R, Lamartine J, Charollais A, Blanchet-Bardon C, Barbe MT, Meda P, Waksman G (2004): Connexin30 mutations responsible for hidrotic ectodermal dysplasia cause abnormal hemichannel activity. Hum Mol Genet 13:1703-1714.

Fänge R, Larsson Å, Lidman U (1972): Fluids and jellies of the acusticolateralis system in relation to body fluids in Coryphaenoides rupestris and other fishes. Marine Biol 17:180-185.

Farris HE, Wells GB, Ricci AJ (2006): Steady-state adaptation of mechanotransduction modulates the resting potential of auditory hair cells, providing an assay for endolymph $\mathrm{Ca}^{2+}$. J Neurosci 26:12526-12536.

Fay RR (1988): Hearing in Vertebrates: A Psychophysics Databook. Winnetka, Hill Fay Associates.

Feng AS, Narins PM, Xu C-H, Lin W-Y, Yu Z-L, Qiu Q, Xu Z-M, Shen J-X (2006): Ultrasonic communication in frogs. Nature 440:333336.

Ferrary E, Bernard C, Oudar O, Sterkers O, Amiel C (1992): Secretion of endolymph by the isolated frog semicircular canal. Acta Otolaryngol 112:294-298.

Fettiplace R (2017): Hair cell transduction, tuning, and synaptic transmission in the mammalian cochlea. Comp Physiol 7:1197-1227.

Fettiplace R, Kim KX (2014): The physiology of mechanoelectrical transduction channels in hearing. Physiol Rev 94:951-986.

Flock A (1965): Transducing mechanisms in the lateral line canal organ receptors. Cold Spring Harb Symp Quant Biol 30:133-145.

Flock $\AA$ (1967): Ultrastructure and function in the lateral line organs; in Cahn P (ed): Lateral Line Detectors. Bloomington, Indiana University Press, pp 163-197.
Flock Å, Jørgensen M, Russell I (1973): The physiology of individual hair cells and their synapses; in Moller A (ed): Basic Mechanisms in Hearing. Cambridge, Academic Press, pp 273-306.

Frank G, Hemmert W, Gummer AW (1999): Limiting dynamics of high-frequency electromechanical transduction of outer hair cells. Proc Natl Acad Sci USA 96:4420-4425.

Fritzsch B, Beisel KW, Jones K, Farinas I, Maklad A, Lee J, Reichardt LF (2002): Development and evolution of inner ear sensory epithelia and their innervation. J Neurobiol 53:143156

Ganeshina OT (1990): The structure of secretory (ion-transporting) elements in the cochlear duct of Caiman crocodilus (Vertebrata, Reptilia). Z Mikrosk-Anat Forsch 104:349-367.

Garvin JL, Spring KR, Santi PA (1988): Secretion of endolymph by semicircular canals of the shark. Am J Physiol 255:F711-F719.

Gaupp EWT (1896): Anatomie des Frosches. Braunschweig, F. Vieweg, vol 2.

Ghaffari R, Page SL, Farrahi S, Sellon JB, Freeman DM (2013): Electrokinetic properties of the mammalian tectorial membrane. Proc Natl Acad Sci USA 110:4279-4284.

Ghanem TA, Breneman KD, Rabbitt RD, Brown HM (2008): Ionic composition of endolymph and perilymph in the inner ear of the oyster toadfish, Opsanus tau. Biol Bull 214:83-90.

Guh YJ, Lin CH, Hwang PP (2015): Osmoregulation in zebrafish: ion transport mechanisms and functional regulation. EXCLI J 14:627659

Hagmann B, Giebel W (1978): Enzymhistochemische Untersuchungen am Innenohr des Frosches (Rana temporaria). Arch Otolaryngol 220:89-103.

Hara J, Plymale DR, Shepard DL, Hara H, Garry $\mathrm{RF}$, Yoshihara T, Zenner H-P, Bolton M, Kalkeri R, Fermin CD (2002): Avian dark cells. Eur Arch Otorhinolaryngol 259:121141

Harada Y, Tagashira N, Hirakawa K (1989): Morphological study of the cells in the planum semilunatum. Acta Otolaryngol 468:17-21.

Harris ML, Baxter LL, Loftus SK, Pavan WJ (2010): Sox proteins in melanocyte development and melanoma. Pigment Cell Melanoma Res 23:496-513.

Hasse C (1868): Das Gehörorgan der Frösche. Leipzig, Wilhelm Engelmann.

Hasse C (1873): Anatomische Studien. Leipzig, Wilhelm Engelmann.

Heffner RS, Heffner HE (1982): Hearing in the elephant (Elephas maximus): absolute sensitivity, frequency discrimination, and sound localization. J Comp Physiol Psychol 96:926944

Held H (1926): Die Cochlea der Säuger und der Vögel, ihre Entwicklung und ihr Bau; in: Receptionsorgane I. Berlin, Springer, pp 467534. 
Helling K, Merker HJ (2005): Morphological aspects of potassium flow in the semicircular canal ampulla of the pigeon. Histol Histopathol 20:339-350.

Henson MM, Henson OW (1988): Tension fibroblasts and the connective tissue matrix of the spiral ligament. Hear Res 35:237-258.

Hibino H, Horio Y, Inanobe A, Doi K, Ito M, Yamada M, Gotow T, Uchiyama Y, Kawamura M, Kubo T, Kurachi Y (1997): An ATP-dependent inwardly rectifying potassium channel, KAB-2 (Kir4. 1), in cochlear stria vascularis of inner ear: its specific subcellular localization and correlation with the formation of endocochlear potential. J Neurosci 17:47114721.

Hibino H, Kurachi Y (2006): Molecular and physiological bases of the $\mathrm{K}^{+}$circulation in the mammalian inner ear. Physiology 21:336345 .

Hibino H, Nin F, Tsuzuki C, Kurachi Y (2010): How is the highly positive endocochlear potential formed? The specific architecture of the stria vascularis and the roles of the iontransport apparatus. Pflugers Arch 459:521533.

Hirokawa N (1980): A freeze-fracture study of intercellular junctions between various kinds of epithelial cells surrounding common endolymphatic space in the hearing organ of the chick. Anat Rec 196:129-143.

Holton T, Weiss TF (1983): Frequency selectivity of hair cells and nerve fibres in the alligator lizard cochlea. J Physiol 345:241-260.

Hommerich CP (1990): Ototoxicity of loop diuretics: morphological and electrophysiological examinations in animal experiments. Adv Otorhinolaryngol 44:92-164.

Hossler FE, Avila FC, Musil G (2002a): $\mathrm{Na}^{+}, \mathrm{K}^{+}-$ ATPase activity and ultrastructural localization in the tegmentum vasculosum in the cochlea of the duckling. Hear Res 164:147-154.

Hossler FE, Olson KR, Musil G, McKamey MI (2002b): Ultrastructure and blood supply of the tegmentum vasculosum in the cochlea of the duckling. Hear Res 164:155-165.

Hwang PP, Chou MY (2013): Zebrafish as an animal model to study ion homeostasis. Pflugers Arch 465:1233-1247.

Hwang PP, Lee TH, Lin LY (2011): Ion regulation in fish gills: recent progress in the cellular and molecular mechanisms. Am J Physiol Regul Integr Comp Physiol 301:R28-R47.

Hyrtl J (1866): Der Seitenkanal von Lota. Sber Akad Wiss 53:551.

Ikeda M, Morgenstern C (1992): Immunohistochemical findings of IgG recognized in the planum semilunatum of the guinea pig. J Laryngol Otol 106:93-97.

Ishiyama E, Cutt RA, Keels EW (1970): Ultrastructure of the tegmentum vasculosum and transitional zone. Ann Otol Rhinol Laryngol 79:998-1009.

ISO (2003): Acoustics - normal equal-loudnesslevel contours. ISO 226:2003. Geneva, International Organization for Standardization.
Ito M, Spicer SS, Schulte BA (1993): Immunohistochemical localization of brain type glucose transporter in mammalian inner ears: comparison of developmental and adult stages. Hear Res 71:230-238.

Iwai T (1967): Structure and development of lateral line cupulae in teleost larvae; in Cahn $\mathrm{P}$ (ed): Lateral Line Detectors. Bloomington, Indiana University Press, pp 27-44.

Jahnke V, Lundquist P-G, Wersäll J (1969): Some morphological aspects of sound perception in birds. Acta Otolaryngol 67:583-601.

Jielof R, Spoor A, de Vries H (1952): The microphonic activity of the lateral line. J Physiol 116:137-157.

Johnson SL, Beurg M, Marcotti W, Fettiplace R (2011): Prestin-driven cochlear amplification is not limited by the outer hair cell membrane time constant. Neuron 70:1143-1154.

Johnstone GC, Schmidt, RS, Johnstone BM (1963): Sodium and potassium in vertebrate cochlear endolymph as dermined by flame microspectrophotometry. Comp Biochem Physiol 9:335-341.

Jorgensen FO (1977): Cochlear potentials of the pigeon inner ear recorded with microelectrodes. Acta Physiol Scand 100:393-403.

Jørgensen JM, Flock A (1973): The ultrastructure of lateral line sense organs in the adult salamander Ambystoma mexicanum. J Neurocytol 2:133-142.

Joyce WG (2015): The origin of turtles: a paleontological perspective. J Exp Zool B Mol Dev Evol 324:181-193.

Katsuki Y, Ushiyama H, Totsuka G (1954): Electrical responses of the single hair cell in the ear of fish. Proc Jap Acad 30:248-255.

Kawasaki K, Yamamoto A, Omori K, Iwano T, Kumazawa T, Tashiro Y (1992): Quantitative immunoelectron microscopic localization of $\mathrm{Na}, \mathrm{K}$-ATPase alpha-subunit in the epithelial cells of rat vestibular apparatus. Hear Res 60: 64-72.

Kelly JP, van Netten SM (1991): Topography and mechanics of the cupula in the fish lateral line. I. Variation of cupular structure and composition in three dimensions. J Morphol 207: 23-36.

Kiernan AE, Steel KP, Fekete DM (2002): Development of the mouse inner ear; in: Rossant J, Tam, Patrick P. L (eds): Mouse Development: Patterning, Morphogenesis, and Organogenesis. San Diego, Academic Press, pp 539-566.

Kikuchi K, Hilding DA (1966): The development of the stria vascularis in the mouse. Acta Otolaryngol 62:277-291.

Kikuchi T, Adams JC, Miyabe Y, So E, Kobayashi $\mathrm{T}$ (2000): Potassium ion recycling pathway via gap junction systems in the mammalian cochlea and its interruption in hereditary nonsyndromic deafness. Med Electron Microsc 33:51-56.

Kikuchi T, Adams JC, Paul DL, Kimura RS (1994): Gap junction systems in the rat vestibular labyrinth: immunohistochemical and ultrastructural analysis. Acta Otolaryngol 114:520-528.
Kim H, Ankamreddy H, Lee DJ, Kong KA, Ko HW, Kim MH, Bok J (2014): Pax3 function is required specifically for inner ear structures with melanogenic fates. Biochem Biophys Res Commun 445:608-614.

Kim SH, Marcus DC (2009): Endolymphatic sodium homeostasis by extramacular epithelium of the saccule. J Neurosci 29:1585115858.

Kim SH, Marcus DC (2011): Regulation of sodium transport in the inner ear. Hear Res 280 : 21-29.

Kimura R, Lundquist PG, Wersaell J (1964): Epithelial linings in the ampullae of the guinea pig labyrinth. Acta Otolaryngol 57:517-530.

Kimura RS (1969): Distribution, structure, and function of dark cells in the vestibular labyrinth. Ann Otol Rhinol Laryngol 78:542-561.

Kok Yd, van der Maarel SM, Bitner-Glindzicz M, Huber I, Monaco AP, Malcolm S, Pembrey ME, Ropers HH, Cremers FP (1995): Association between $\mathrm{X}$-linked mixed deafness and mutations in the POU domain gene POU3F4. Science 267:685-688.

Köppl C (1997): Phase locking to high frequencies in the auditory nerve and cochlear nucleus magnocellularis of the barn owl, Tyto alba. J Neurosci 17:3312-3321.

Krause R (1922): Mikroskopische Anatomie der Wirbeltiere in Einzeldarstellungen, II. Voegel und Reptilien. Berlin, W de Gruyter.

Kronester-Frei A (1979): The effect of changes in endolymphatic ion concentrations on the tectorial membrane. Hear Res 1:81-94.

Kuhn A (1880): Ueber das häutige Labyrinth der Amphibien. Arch Mikrosk Anat 17:479-550.

Kuijpers W, Houben NMD, Bonting SL (1970): Distribution and properties of ATPase activities in the cochlea of the chicken. Comp Biochem Physiol 36:669-676.

Kuijpers W, Peters TA, Tonnaer EL, Ramaekers FC (1991): Expression of cytokeratin polypeptides during development of the rat inner ear. Histochemistry 96:511-521.

Kuijpers W, van der Vleuten AC, Bonting SL (1967): Cochlear function and sodium and potassium activated adenosine triphosphatase. Science 157:949-950.

Lee JH, Chiba T, Marcus DC (2001): P2X2 receptor mediates stimulation of parasensory cation absorption by cochlear outer sulcus cells and vestibular transitional cells. J Neurosci 21:9168-9174.

Levy C, Khaled M, Fisher DE (2006): MITF: master regulator of melanocyte development and melanoma oncogene. Trends Mol Med 12: 406-414.

Liddicoat JD, Roberts BL (1972): The ionic composition of the lateral-line canal fluid of dogfish. J Mar Biol Ass 52:653.

Lim DJ (1986): Functional structure of the organ of Corti: a review. Hear Res 22:117-146.

Lindeman HH (1969): Studies on the morphology of the sensory regions of the vestibular apparatus with 45 figures. Ergeb Anat Entwicklungsgesch 42:1-113. 
Lowenstein O, Osborne MP, Thornhill RA (1968): The anatomy and ultrastructure of the labyrinth of the lamprey (Lampetra fluviatilis L.). Proc Royal Soc Lond B Biol Sci 170:113134.

Lukashkina VA, Levic S, Lukashkin AN, Strenzke N, Russell IJ (2017): A connexin30 mutation rescues hearing and reveals roles for gap junctions in cochlear amplification and micromechanics. Nat Commun 8:14530.

Manley GA (2012): Evolutionary paths to mammalian cochleae. J Assoc Res Otolaryngol 13: 733-743.

Manley GA (2017): The mammalian Cretaceous cochlear revolution. Hear Res 352:23-29.

Manley GA, Clack JA (2004): An outline of the evolution of vertebrate hearing organs; in: Manley GA, Popper AN, Fay RR (eds): Springer Handbook of Auditory Research: Evolution of the Vertebrate System. New York, Springer, pp 1-26.

Manley GA, Kronester-Frei A (1980): Organ of Corti: observation technique in the living animal. Hear Res 2:87-91.

Manley GA, Robertson D (1976): Analysis of spontaneous activity of auditory neurones in the spiral ganglion of the guinea-pig cochlea. J Physiol 258:323-336.

Manley GA, Sienknecht U, Köppl C (2004): Calcium modulates the frequency and amplitude of spontaneous otoacoustic emissions in the bobtail skink. J Neurophysiol 92:2685-2693.

Manley GA, Wartini A, Schwabedissen G, Siegl E (2018): Spontaneous otoacoustic emissions in teiid lizards. Hear Res 363:98-108.

Marcus DC, Chiba T (1999): $\mathrm{K}^{+}$and $\mathrm{Na}^{+}$absorption by outer sulcus epithelial cells. Hear Res 134:48-56.

Mason MJ, Segenhout JM, Cobo-Cuan A, Quinones PM, van Dijk P (2015): The frog inner ear: picture perfect? J Assoc Res Otolaryngol 16:171-188.

Mayer-Gostan N, Kossmann H, Watrin A, Payan P, Boeuf G (1997): Distribution of ionocytes in the saccular epithelium of the inner ear of two teleosts (Oncorhynchus mykiss and Scophthalmus maximus). Cell Tissue Res 289:5361.

McGlone FP, Russell IJ, Sand O (1979): Measurement of calcium ion concentrations in the lateral line cupulae of Xenopus laevis. J Exp Biol 83:123-130.

McHenry MJ, van Netten SM (2007): The flexural stiffness of superficial neuromasts in the zebrafish (Danio rerio) lateral line. J Exp Biol 210:4244-4253.

Meyer zum Gottesberge AM (1988a): Modulation of melanocytes during experimentally induced endolymphatic hydrops. Acta Histochem 36:331-339.

Meyer zum Gottesberge AM (1988b): Physiology and pathophysiology of inner ear melanin. Pigment Cell Res 1:238-249.
Minowa O, Ikeda K, Sugitani Y, Oshima T, Nakai S, Katori Y, Suzuki M, Furukawa M, Kawase T, Zheng Y, Ogura M, Asada Y, Watanabe K, Yamanaka H, Gotoh S, Nishi-Takeshima M, Sugimoto T, Kikuchi T, Takasaka T, Noda T (1999): Altered cochlear fibrocytes in a mouse model of DFN3 nonsyndromic deafness. Science 285:1408-1411.

Misrahy GA, Hildreth KM, Schinabarger EW, Gannon WJ (1958): Electrical properties of wall of endolymphatic space of the cochlea (guinea pig). Am J Physiol 194:396-402.

Mulroy MJ (1968): Ultrastructure of the basilar papilla of reptiles; $\mathrm{PhD}$ dissertation, San Francisco.

Müntz H (1989): Functional organization of the lateral line periphery; in Coombs S, Görner P, Münz H (eds): The Mechanosensory Lateral Line: Neurobiology and Evolution. Berlin, Springer Science and Business Media, pp 285-298.

Munyer PD, Schulte BA (1991): Immunohistochemical identification of proteoglycans in gelatinous membranes of cat and gerbil inner ear. Hear Res 52:369-378.

Murray RW (1960): Electrical sensitivity of the ampullæ of lorenzini. Nature 187:957.

Murray RW, Potts WTW (1961): The composition of the endolymph, perilymph and other body fluids of elasmobranchs. Comp Biochem Physiol 2:65-75.

Nakazawa K, Spicer SS, Gratton MA, Schulte BA (1996): Localization of actin in basal cells of stria vascularis. Hear Res 96:13-19.

Necker R (1970): Zur Entstehung der Cochleapotentiale von Vögeln: Verhalten bei $\mathrm{O}_{2}$-Mangel, Cyanidvergiftung und Unterkühlung sowie Beobachtungen über die rämliche Verteilung. Z Vergl Physiol 69:367-425.

Netten SM, Kroese ABA (1989): Dynamic behavior and micromechanical properties of the $\mathrm{cu}$ pula; in: Coombs S, Görner P, Münz H (eds): The Mechanosensory Lateral Line: Neurobiology and Evolution. Berlin, Springer Science and Business Media, pp 247-263.

Nilsen KE, Russell IJ (1999): Timing of cochlear feedback: spatial and temporal representation of a tone across the basilar membrane. Nat Neurosci 2:642-648.

Nin F, Yoshida T, Sawamura S, Ogata G, Ota T, Higuchi T, Murakami S, Doi K, Kurachi Y, Hibino H (2016): The unique electrical properties in an extracellular fluid of the mammalian cochlea; their functional roles, homeostatic processes, and pathological significance. Pflugers Arch 468:1637-1649.

Ninoyu O, Hommerich C, Morgenstern C (1987): Endolymph formation in the inner ear of pigeons. ORL J Otorhinolaryngol Relat Spec 49: $1-8$.

Nothwang HG (2016): Evolution of mammalian sound localization circuits: a developmental perspective. Prog Neurobiol 141:1-24.

Palmer AR, Russell IJ (1986): Phase-locking in the cochlear nerve of the guinea-pig and its relation to the receptor potential of inner haircells. Hear Res 24:1-15.
Passeron T, Valencia JC, Bertolotto C, Hoashi T, Le Pape E, Takahashi K, Ballotti R, Hearing VJ (2007): SOX9 is a key player in ultraviolet Binduced melanocyte differentiation and pigmentation. Proc Natl Acad Sci USA 104: 13984-13989.

Paterson NF (1960): The inner ear of some members of the Pipidae (Amphibia). Proc Zool Soc Lond 134:509-546.

Patthey C, Schlosser G, Shimeld SM (2014): The evolutionary history of vertebrate cranial placodes - I: cell type evolution. Dev Biol 389: 82-97.

Patuzzi R (2011): Ion flow in stria vascularis and the production and regulation of cochlear endolymph and the endolymphatic potential. Hear Res 277:4-19.

Peter I, Davidson E (2015): Genomic Control Process: Development and Evolution. Cambridge, Academic Press.

Peterson SK, Frishkopff LS, Lechène C, Oman CM, Weiss TF (1978): Element composition of inner ear lymphs in cats, lizards, and skates determined by electron probe microanalysis of liquid samples. J Comp Physiol 126:1-14.

Pickles JO (2013): An Introduction to the Physiology of Hearing, ed 4. Leiden, Brill.

Pisam M, Payan P, LeMoal C, Edeyer A, Boeuf G, Mayer-Gostan N (1998): Ultrastructural study of the saccular epithelium of the inner ear of two teleosts, Oncorhynchus mykiss and Psetta maxima. Cell Tissue Res 294:261-270.

Pondugula SR, Raveendran NN, Ergonul Z, Deng Y, Chen J, Sanneman JD, Palmer LG, Marcus DC (2006): Glucocorticoid regulation of genes in the amiloride-sensitive sodium transport pathway by semicircular canal duct epithelium of neonatal rat. Physiol Genomics 24:114-123.

Pondugula SR, Sanneman JD, Wangemann P, Milhaud PG, Marcus DC (2004): Glucocorticoids stimulate cation absorption by semicircular canal duct epithelium via epithelial sodium channel. Am J Physiol 286:F1127F1135.

Popper P, Winkler J, Erbe CB, Lerch-Gaggl A, Siebeneich W, Wackym PA (2008): Distribution of two-pore-domain potassium channels in the adult rat vestibular periphery. Hear Res 246:1-8.

Retzius G (1881): Das Gehörorgan der Wirbelthiere Morphologisch-Histologische Studien. I. Das Gehörorgan der Fische und Amphibien. Stockholm, Samson and Wallin.

Retzius G (1884): Das Gehörorgan der Wirbelthiere Morphologisch - Das Gehörorgan de Wirbelthiere Histologische Studien. II. Das Gehörorgan der Reptilien, der Vögel und der Säugethiere. Stockholm, Samson and Wallin.

Ricci AJ, Wu YC, Fettiplace R (1998): The endogenous calcium buffer and the time course of transducer adaptation in auditory hair cells. J Neurosci 18:8261-8277. 
Roberts BL, Ryan KP (1971): The fine structure of the lateral-line sense organs of dogfish. Proc Biol Sci 179:157-169.

Rosenhall U (1971): Morphological patterns of the organ of Corti in birds. Arch Klin Exp Ohren Nasen Kehlkopfheilkd 200:42-63.

Runhaar G, Manley GA (1987): Potassium concentration in the inner sulcus is perilymphlike. Hear Res 29:93-103.

Runhaar G, Schedler J, Manley GA (1991): The potassium concentration in the cochlear fluids of the embryonic and post-hatching chick. Hear Res 56:227-238.

Russell IJ (1976): Amphibian Lateral Line Receptors; in: Llinás R, Precht W (eds): Frog Neurobiology: A Handbook. Berlin, Springer, pp 513-550.

Russell IJ (1983): Origin of the receptor potential in inner hair cells of the mammalian cochleaevidence for Davis' theory. Nature 301:334336.

Russell IJ, Cody AR, Richardson GP (1986): The responses of inner and outer hair cells in the basal turn of the guinea-pig cochlea and in the mouse cochlea grown in vitro. Hear Res 22 : 199-216.

Russell IJ, Sellick PM (1976): Measurement of potassium and chloride ion concentrations in the cupulae of the lateral lines of Xenopus laevis. J Physiol 257:245-255.

Russell IJ, Sellick PM (1977): Tuning properties of cochlear hair cells. Nature 267:858-860

Russell IJ, Sellick PM (1983): Low-frequency characteristics of intracellularly recorded receptor potentials in guinea-pig cochlear hair cells. J Physiol 338:179-206.

Sagara T, Furukawa H, Makishima K, Fujimoto S (1995): Differentiation of the rat stria vascularis. Hear Res 83:121-132.

Salt AN, Inamura N, Thalmann R, Vora A (1989): Calcium gradients in inner ear endolymph. Am J Otolaryngol 10:371-375.

Sand O (1975): Effects of different ionic environments on the mechano-sensitivity of lateral line organs in the mudpuppy. J Comp Physiol 102:27-42.

Santi PA, Anderson CB (1987): A newly identified surface coat on cochlear hair cells. Hear Res 27:47-65.

Sato M (1962): Studies on the pit organs of fishes $\mathrm{V}$. The structure and polysaccharide histochemistry of the cupula pit organ. Annot Zool Jpn 35:88.

Satoh N (1917): Der histologische Bau der Vogelschnecke und ihre Schädigung durch akustische Reize und durch Detonation, mit $6 \mathrm{Ab}$ bildungen im Text und 55 Abbildungen auf Tafeln. Basel, Schwabe.

Sauer G, Richter CP, Klinke R (1999): Sodium, potassium, chloride and calcium concentrations measured in pigeon perilymph and endolymph. Hear Res 129:1-6.

Schermuly L, Vossieck T, Klinke R (1990): Furosemide has no effect on endocochlear potential and tuning properties of primary afferent fibres in the pigeon inner ear. Hear Res 50: 295-298.
Schmidt RS (1963a): Independence of the endovestibular potential in homeotherms. J Gen Physiol 47:371-378.

Schmidt RS (1963b): Types of endolymphatic potentials. Comp Med 10:83-87.

Schmidt RS, Fernandez C (1962): Labyrinthine DC potentials in representative vertebrates. Comp Biochem Physiol 59:311-322.

Schneider ME, Cotanche DA, Fambrough DM, Saunders JC, Matschinsky FM (1987): Immunocytochemical and quantitative studies of $\mathrm{Na}^{+}, \mathrm{K}^{+}$-ATPase distribution in the developing chick cochlea. Hear Res 31:39-53.

Schulze FE (1861): Uber die Nervenendigung in den sogenannten Schleimkanalen der Fische und uber entsprechende Organe der durch Kiemen athmenden Amphibien. Arch Anat Physiol Lpz 759:769.

Sher AE (1971): The embryonic and postnatal development of the inner ear of the mouse. Acta Otolaryngol 285:1-77.

Smith CA (1970): The extrasensory cells of the vestibule; in: Biochemical Mechanisms in Hearing and Deafness. Springfield, Charles C. Thomas, pp 171-185.

Smith CA, Davis H, Deatherage BH, Gessert CF (1958): DC potentials of the membranous labyrinth. Am J Physiol 193:203-206.

Smith CA, Lowry OH, Wu ML (1954): The electrolytes of the labyrinthine fluids. Laryngoscope 64:141-153.

Smith GM (1933): The mechanism of intake and outflow of fluids in the lateral line canal of fishes. Anat Rec 56:365-371.

Song MH, Choi SY, Wu L, Oh SK, Lee HK, Lee DJ, Shim DB, Choi JY, Kim UK, Bok J (2011): Pou3f4 deficiency causes defects in otic fibrocytes and stria vascularis by different mechanisms. Biochem Biophys Res Commun 404: 528-533.

Spicer SS, Schulte BA (1996): The fine structure of spiral ligament cells relates to ion return to the stria and varies with place-frequency. Hear Res 100:80-100.

Steel KP (1983): The tectorial membrane of mammals. Hear Res 9:327-359.

Sterkers O, Bernard C, Ferrary E, Sziklai I, Tran Ba Huy P, Amiel C (1988): Possible role of Ca ions in the vestibular system. Acta Otolaryngol 460:28-32.

Tachibana M (1999): Sound needs sound melanocytes to be heard. Pigment Cell Res 12:344354

Takagi Y (1997): Meshwork arrangement of mitochondria-rich, $\mathrm{Na}^{+}, \mathrm{K}^{+}$-ATPase-rich cells in the saccular epithelium of rainbow trout $(\mathrm{On}$ corhynchus mykiss) inner ear. Anat Rec 248: 483-489.

Takei Y, Hiroi J, Takahashi H, Sakamoto T (2014): Diverse mechanisms for body fluid regulation in teleost fishes. Am J Physiol Regul Integr Comp Physiol 307:R778-R792.

Tasaki I (1957): Hearing. Annu Rev Physiol 19: $417-438$
Tasaki I, Spyropoulos CS (1959): Stria vascularis as source of endocochlear potential. J Neurophysiol 22:149-155.

ten Cate WJ, Rarey KE (1992): Planum semilunatum of the rat: new light and electron microscopy observations. Ann Otol Rhinol Laryngol 101:601-606.

Thomopolous A (1958): Sur la ligne latérale des Téléostiéns. II. La cupule et les neuromasts chez des embryons et des larves planctoniques d'espéces marines. Bull Soc Zool Fr 82:437.

Torroba M, Barrutia MG, Zapata AG (1988): Morphological, histochemical, and ultrastructural characterization of the accessory cells of neuromasts in the salamander Pleurodeles waltlii. Cell Tissue Res 254:233-240.

Treviranus GR (1924): Über den inneren Bau der Schnecke des Ohrs der Vögel; in: Tiedemann F, Treviranus GR, Treviranus LC (eds): Untersuchungen über die Natur des Menschen, der Thiere under Pflanzen. Heidelberg, Leipzig, pp 188-196.

Trincker D (1957): Bestandspotentiale im Bogengangssystem des Meerschweinchens und ihre Anderungen bei experimentellen CupulaAblenkungen. Pflugers Arch Gesamte Physiol Menschen Tiere 264:351-382.

Trincker D (1962): The transformation of mechanical stimulus into nervous excitation by the labyrinthine receptors. Symp Soc Exp Biol 16:289-316.

Trowe M-O, Maier H, Petry M, Schweizer M, Schuster-Gossler K, Kispert A (2011): Impaired stria vascularis integrity upon loss of E-cadherin in basal cells. Dev Biol 359:95107.

Trowe M-O, Maier H, Schweizer M, Kispert A (2008): Deafness in mice lacking the T-box transcription factor Tbx18 in otic fibrocytes. Development 135:1725-1734.

Trowe M-O, Shah S, Petry M, Airik R, SchusterGossler K, Kist R, Kispert A (2010): Loss of Sox9 in the periotic mesenchyme affects mesenchymal expansion and differentiation, and epithelial morphogenesis during cochlea development in the mouse. Dev Biol 342:51-62.

van Netten SM, Kroese AB (1987): Laser interferometric measurements on the dynamic behaviour of the cupula in the fish lateral line. Hear Res 29:55-61.

Vidal N, Hedges SB (2009): The molecular evolutionary tree of lizards, snakes, and amphisbaenians. C R Biol 332:129-139.

Villegas $\mathrm{H}$, Merker HJ, Helling K, Clarke AH, Scherer H (2001): Electron microscopic studies of ion- and $\mathrm{H}_{2} \mathrm{O}$-transporting epithelial cells in the horizontal ampulla of the pigeon. Histol Histopathol 16:1161-1174.

Vilstrup T, Jensen CE (1961): On the displacement potential in acid mucopolysaccharides. Acta Otolaryngol 163:42-46.

von Békésy G (1952): DC resting potentials inside the cochlear partition. J Acoust Soc Am 24:72.

Wagner DS (1934): The structure of the inner ear in relation to the reduction of the middle ear in the Liopelmidae (Noble). Anat Anz 79:2036. 
Wagner DS (1935): On the cranial characters of Liopelma hochstetteri. Anat Anz 79:65-77.

Wangemann P (1995): Comparison of ion transport mechanisms between vestibular dark cells and strial marginal cells. Hear Res 90: 149-157.

Wangemann $\mathrm{P}$ (2002): $\mathrm{K}^{+}$cycling and its regulation in the cochlea and the vestibular labyrinth. Audiol Neurootol 7:199-205.

Wangemann P (2006): Supporting sensory transduction: cochlear fluid homeostasis and the endocochlear potential. J Physiol 576:11-21.

Wangemann P, Marcus DC (1989): Membrane potential measurements of transitional cells from the crista ampullaris of the gerbil. Effects of barium, quinidine, quinine, tetraethylammonium, cesium, ammonium, thallium and ouabain. Pflugers Arch 414:656-662.
Wangemann P, Schacht J (1996): Homeostatic mechanisms in the cochlea; in: Dallos P, Popper A, Fay R (eds): The Cochlea: Springer Handbook of Auditory Research. Berlin, Springer, pp 130-185.

Weiss TF, Altmann DW, Mulroy MJ (1978): Endolymphatic and intracellular resting potential in the alligator lizard cochlea. Pflugers Arch Eur J Physiol 373:77-84.

Wilms V, Köppl C, Söffgen C, Hartmann A-M, Nothwang HG (2016): Molecular bases of $\mathrm{K}^{+}$ secretory cells in the inner ear: shared and distinct features between birds and mammals. Sci Rep 6:34203.
Wilms V, Söffgen C, Nothwang HG (2017): Differences in molecular mechanisms of $\mathrm{K}^{+}$ clearance in the auditory sensory epithelium of birds and mammals. J Exp Biol 220:27012705.

Yoshihara T, Fermin CD, Igarashi M (1987): Localization of $\mathrm{Na}^{+}, \mathrm{K}^{+}$-ATPase activity in the tegmentum vasculosum of the chick cochlea. Arch Otorhinolaryngol 243:401-402.

Yoshihara T, Igarashi M, Fermin CD (1990): Ultracytochemical localization of $\mathrm{Na}^{+}, \mathrm{K}^{+}-$ ATPase activity in the tegmentum vasculosum of the developing chick cochlea. Acta Otolaryngol 110:366-373.

Zidanic M, Brownell WE (1990): Fine structure of the intracochlear potential field. I. The silent current. Biophys J 57:1253-1268. 